\title{
Molecular basis of barley quality
}

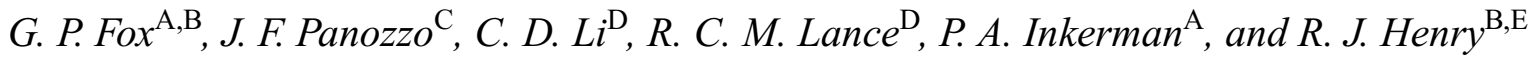 \\ ${ }^{A}$ Department of Primary Industries, Agency for Food and Fibre Sciences, Farming Systems, Toowoomba, \\ Qld 4350, Australia. \\ ${ }^{\mathrm{B}} \mathrm{CRC}$ for Innovative Grain Food Products, Centre for Plant Conservation Genetics, Southern Cross University, \\ PO Box 157, Lismore, NSW 2480, Australia. \\ ${ }^{\mathrm{C}}$ Department of Primary Industries, Victorian Institute for Dryland Agriculture, PO Box 260, Horsham, \\ Vic. 3401, Australia. \\ Department of Agriculture, 3 Baron Hay Court, South Perth, WA 6150, Australia. \\ ${ }^{\mathrm{E}}$ Corresponding author; email: rhenry@scu.edu.au
}

\begin{abstract}
The quality of barley for the range of end uses from animal feed to brewing is determined by many genes, making the breeding of new barley varieties difficult. Understanding of the molecular basis of barley quality has been advanced by biochemical studies. More recently, molecular genetic tools are allowing the analysis of the biochemical factors contributing to grain quality. Many genetic loci influencing key quality attributes have been identified by gene mapping. Limited success has been reported in using this information to select for quantitative trait loci for these quality traits in plant breeding. Genomic techniques allowing more detailed analysis of variations in the barley genome in relation to quality promise to extend significantly the value of molecular genetic approaches to barley quality improvement. Definition of the genetic basis of malting quality requires the identification of the genes involved in germination and endosperm modification. Feed quality remains difficult to define. Recent advances are likely to accelerate the rate of discovery, providing new options for analysis of barley quality.
\end{abstract}

Additional keywords: malting, genetics, feed, barley end-use, QTL.

\section{Introduction}

Barley is used for a wide range of traditional (Edney 1996) and novel (Sparrow et al. 1988) end uses. Barley is fed to animals as a significant part of the diet of cattle, pigs, and poultry. Human food uses of barley are more limited. A significant high-value use is for malting to produce malt as a raw material for the brewing of beer and fermentation and distillation for the production of whisky.

Barley production to supply these diverse end uses requires barley breeding programs to provide varieties with the combination of reliable and efficient production characteristics and grain quality attributes suited to these uses. Selection of varieties with the complex range of traits necessary for efficient processing to produce high quality products such as beer is a difficult process. Testing of end product quality for each line is not only expensive but requires the availability of larger quantities of barley than is available from single plants or lines at an early stage in barley breeding. Biochemical or molecular tests that predict likely feed or malting and brewing quality are therefore needed to allow rapid development of barley varieties. The biochemical basis of several barley quality traits is not well understood. Many of the traditional testing and evaluation methods aim to ensure a consistency of quality without the link between the attribute measured and the end-use quality being known. This results in large numbers of attributes of uncertain value being assessed to reduce the risk of adopting or using barley that causes difficulties in processing or end product quality. This process may discriminate against barley with superior processing traits and will only be overcome by improved understanding of the basis of barley quality, especially at the biochemical and genetic levels. This is highlighted when comparing our understanding of barley carbohydrates and the enzymes that degrade them with protein breakdown and the proteinases. Detailed research has uncovered many aspects of barley carbohydrate chemistry and the function of individual components in terms of feed, malt, and beer quality. The important role of 
Table 1. Barley quality specifications for malting and feed end users

\begin{tabular}{|c|c|c|}
\hline Trait & Malting range & Feed range \\
\hline \multicolumn{3}{|c|}{ Barley industry specifications (hulled grain) } \\
\hline \multicolumn{3}{|l|}{ Grain size } \\
\hline$>2.5 \mathrm{~mm}$ & $>70 \%$ & $>40 \%$ \\
\hline$<2.2 \mathrm{~mm}$ & $<5 \%$ & $<15 \%$ \\
\hline Protein & $10.0-12.0 \% \mathrm{db}$ & n.a. \\
\hline Moisture & $12.5 \% \max$. & $12.5 \%$ max. \\
\hline \multicolumn{3}{|l|}{ Weather damage } \\
\hline Falling number & $>300 \mathrm{~s}$ & n.a. \\
\hline RVA & $>150$ units & n.a. \\
\hline Test weight & $65.0 \mathrm{~kg} / \mathrm{hL}$ & $62.5 \mathrm{~kg} / \mathrm{hL}$ \\
\hline \multicolumn{3}{|c|}{ Non-industry specifications (desirable breeding priorities) } \\
\hline Husk & $8.0-10.0 \% \mathrm{db}$ & \\
\hline$\beta$-Glucan (\%) & $3.0-5.0$ & $>5,<6$ (poultry) \\
\hline \multicolumn{3}{|l|}{ Hardness } \\
\hline Comparamill & $<250$ & \\
\hline SKCS & $<30$ & $>40$ \\
\hline Particle size & & $1000-2000 \mu \mathrm{m}$ \\
\hline Starch & $55.0-65.0 \% \mathrm{db}$ & $>60 \% \mathrm{db}$ \\
\hline Digestibility (DMD) & & $>50(20-60)$ \\
\hline \multicolumn{3}{|l|}{ Fibre } \\
\hline $\mathrm{ADF}$ & & $5.0-10.0 \% \mathrm{db}$ (lower better) \\
\hline NDF & & $15.0-30.0 \% \mathrm{db}$ \\
\hline \multicolumn{3}{|l|}{ Fermentation (in vitro) } \\
\hline$\%$ Starch digested & & $52-76 \%$ \\
\hline Enzyme digestion & & $37-53 \%$ \\
\hline Hot water extract: EBC (fine) & $80.0-83.0 \%$ & \\
\hline Kolbach index & $35.0-49.9$ & \\
\hline \multicolumn{3}{|l|}{ Diastatic power } \\
\hline EBC WK & $200-350$ & \\
\hline $\mathrm{U} / \mathrm{g}$ & $300-600$ & \\
\hline Viscosity & $1.55-1.65 \mathrm{cP}$ & \\
\hline Fermentability & $78.0-86.0 \%$ & \\
\hline Wort $\beta$-glucan & $0-200 \mathrm{mg} / \mathrm{L}$ & \\
\hline \multicolumn{3}{|l|}{$\alpha$-Amylase } \\
\hline $\mathrm{U} / \mathrm{g}$ & $>150$ & \\
\hline DU & $>60$ & \\
\hline Free amino $\mathrm{N}$ & $140-180$ mg/L & \\
\hline Friability & Min. 70\% & \\
\hline$\beta$-Glucanase & $>250 \mathrm{U} / \mathrm{g}$ & \\
\hline
\end{tabular}

n.a., not available.

protein breakdown during malting and the residual protein components in beer has only started to be understood and requires further research

The Australian malting and brewing industry consider 6 parameters to be most important in defining malt quality (Table 1). These are hot water extract, viscosity, Kolbach index, wort $\beta$-glucan, fermentability, and diastatic power. Other include $\alpha$-amylase, free amino nitrogen, friability, and $\beta$-glucanase. However, an important dilemma arises in the case of malt quality. The value of parameters currently used to measure malt quality has been questioned by various groups over the past decade (MacGregor 1996; Palmer 1983) and their limitations in predicting brewery performance have led to suggestions (Axcell 1998) that specific brewery tests were also needed to adequately describe malt quality.

The molecular basis of barley quality is understood to varying degrees in relation to different quality traits. Hot water extract (Collins et al. 2003, this issue), grain size (Coventry et al. 2003b, this issue), diastatic power (Coventry et al. 2003a, this issue), dormancy (Li et al. 2003, this issue), and grain protein (Emebiri et al. 2003, this issue) have been covered in detail. This review identifies the key barley and malt quality traits and our understanding of their biochemical basis. A complete understanding of the 
molecular genetic basis of quality requires consideration of the interaction of genotype with the growth environment in determining the quality of the grain. The known genes are described and the likely impact of future developments based upon genomics is explored.

\section{Barley quality traits}

\section{Grain protein}

Barley protein accounts for $8-13 \%$ (dry basis) of malting quality barley, while anecdotal evidence suggests that $12-13 \%$ protein is most efficient for ruminant animals. Barley protein has a complex interaction with quality. High protein is undesirable because of the strong correlation with low carbohydrate levels and thus low extract values (Bishop 1930). However, if the protein content of malt is too low, brewing performance may be impaired through poor yeast amino acid nutrition. Protein levels in packaged beer are important, positively enhancing foam stability and negatively influencing shelf life by contributing to chill hazes. Many proteins have been identified with specific functions in terms of grain and malt quality, whereas a number have yet to have their function clearly defined.

\section{Storage proteins}

Storage proteins exist in all cereals. This protein component forms a matrix around starch granules in the endosperm and provides a source of nitrogen for the growing embryo if germination occurs. These proteins are generally rich in the amino acids proline and glutamine (hence the term prolamine). In barley, the major storage protein is called hordein, and this comprises $40-50 \%$ of total grain protein. This component is soluble in aqueous alcohol and comprises 4 fractions designated D, C, B, and A. The diversity in the hordein family has made the analysis of these fractions very useful in varietal identification. This diversity can be explained through differences within the $\mathrm{B}$ and $\mathrm{C}$ hordeins that occur between varieties, as well as grain protein levels and environments (Benetrix et al. 1994; Molina-Cano et al. $2000 b$ ). Several hordein proteins have been purified and sequenced. However, the roles of the specific subunits remain undefined. This particular cereal protein component has been comprehensively reviewed by Shewry (1993).

\section{Hordeins, malting and brewing quality}

For over 100 years, researchers have attempted to describe the negative relationship between protein and hot water extract. Smith (1990), Shewry (1993), and Tatham and Shewry (1995) provided excellent reviews of previously published results on this subject. Whereas Bishop (1930) concluded that there was a negative relationship between protein and hot water extract, details from these reviews showed that each hordein group had some relationship to extract or final beer quality. In particular, aggregation of the sulfur-rich B and D groups forms gels which cause filtration problems in brewing, and individual B and C (sulfur-poor) groups have variable effects on extract (Skerritt and Janes 1992; Janes and Skerritt 1993). Initial studies by Marchylo et al. (1986) demonstrated the difference in hordein breakdown during the malting of 2 varieties of differing quality. The malting variety was reported to give a higher level of modification than the non-malting. This was reflected in the hordein analysis where the malting variety exhibited a higher level of hordein breakdown. Recently, several studies have described a negative correlation between $\mathrm{D}$ hordein and hot water extract (Howard et al. 1996; Molina-Cano et al. 2000 b). In contrast, Brennan et al. (1998) found that with D hordein isogenic lines there was no effect on extract, although the presence or absence of a D hordein allele had an impact on gel protein formation. Further, Brennan et al. (1998) related grain hardness, in the form of milling energy, to specific $\mathrm{B}$ and $\mathrm{C}$ hordein alleles. However, 2 recent cases note a positive relationship between individual hordein fractions and malt quality. Janes and Skerritt (1993) reported a B hordein fraction with a positive effect on hot water extract, whereas Molina-Cano et al. (1995) suggested that a C hordein had a positive effect on water uptake during malting. Many of these observations may be explained by indirect effects of the levels of one group of proteins on total protein or the levels of other specific protein components.

Several studies have examined the effect of hordein breakdown products on beer quality. Kauffman et al. (1994), using monoclonal antibodies, identified the presence of $\mathrm{D}$ and $\mathrm{B}$ hordein components in lager foam, whereas $\mathrm{C}$ hordein components could not be detected. ELISAs have also been used to identify polypeptides derived from B, C, and D hordein in beer and beer foam (Sheehan and Skerritt 1997). Although large proline-rich polypeptides influence chill haze formation (Asano et al. 1982), smaller hydrophobic polypeptides have positive effects on foam formation. Hence, several important factors should be considered when investigating beer and beer foam quality, including the initial barley hordein profile, malt hordein profile, level of modification, mashing conditions, and the possible interaction of polyphenols and additional proteins such as protein $\mathrm{Z}$ and lipid transfer proteins (LTPs).

\section{Non-storage proteins}

Many non-storage proteins exist within the cell walls as well as within the protein matrix. However, very few have been identified as having an impact on quality. Cell walls contain glycine-rich protein, as well as threonine-rich and hydroxyproline-rich glycoproteins (Cassab and Varner 1988; Kieliszewski et al. 1990). A structural protein, friabilin, has been isolated from barley endosperm. This protein has been identified with wheat puroindoline antibodies (Darlington et al. 2000). It has a molecular weight of around 15000, 
which is similar to the wheat protein. Currently, the function of this protein remains unclear. However, it has been proposed that friabilin may have a role in grain hardness, by binding the protein matrix with starch granules. Darlington et al. (2000) reported an increased level of friabilin extracted in soft wheat and 'soft' barley. In contrast, more friabilin remained attached to the starch granules in hard wheat and barley.

\section{Protein Z}

Protein $\mathrm{Z}$ comprises a family of serine proteinase inhibitors (Dahl et al. 1996), which have been associated with specific effects on beer quality, in particular the stabilisation of beer foams (Hejgaard and Kaesgaard 1983). However, Lusk et al. (1995) demonstrated that protein Z alone was not the main foam-stabilising protein in beer foam. This suggestion was supported by work which demonstrated that Pirkka, a Finnish barley variety containing no protein $\mathrm{Z}$, could still produce acceptable beer foam (Gibson et al. 1996). Thus, it is evident that many factors are involved in the formation and stabilisation of beer foam.

The effects of germination, kilning, and mashing on Protein Z4 and Protein Z7 have been reported (Evans and Hejgaard 1999; Evans et al. 1999). Both proteins exist in barley in free and bound forms. The levels of the bound form have been found to increase during germination, whereas kilning decreases the level. Protein Z4 showed a significant $(P<0.05)$ positive correlation with foam, for beer produced from high temperature infusion mashes and low temperature ramping mashes (Evans et al. 1999). Protein $Z$ can be found in bound form as a hetero-dimer with $\beta$-amylase, which can be cleaved by malt endopeptidase to produce a free form and thus activate the $\beta$-amylase (Guerin et al. 1992)

\section{Lipid transfer proteins}

Lipid transfer protein 1 (LTP1) is another structural protein involved in the binding of lipid and starch within the endosperm. LTP1 has been found in beer foam and implicated in foam retention, although there is a minor modification from the form in barley to that detected in beer (Sorensen et al. 1993). Lusk et al. (1995) suggested a strong positive effect on beer foam for a protein identified as LTP1. In contrast, Evans et al. (1999) showed a non-significant correlation between LTP1 and beer head retention. Evans and Hejgaard (1999) reported varietal differences for LTP1, and although LTP1 survived the kilning process, the level was reduced. It has been suggested that LTP1 inhibits cysteine endoproteinases (Jones and Marinac 1995). A second cysteine inhibitor, named LTP2, has been identified by the same authors. This barley protein survived kilning and, like LTP1, may have a role in controlling the rate of storage protein hydrolysis during malting and mashing. It is not known whether LTP2 has a role in beer foam stability.

\section{Barley carbohydrates}

Barley carbohydrate composition has been one of the most studied aspects in terms of barley quality and its relation to feed, malt, and beer quality. Henry (1988) reviewed the current knowledge of barley carbohydrate composition in terms of malt quality, concluding that despite many years of research, our knowledge of barley carbohydrate chemistry was incomplete. Further work was required to fully understand barley carbohydrates before significant genetic gain was reached. More recent reviews have covered the topic in similar detail (Duffus and Cochrane 1993; Swantson and Ellis 2002). In this section we will cover the basics of barley carbohydrates as well as review the most recent research.

\section{Starch}

Starch is the most abundant component of the endosperm, comprising around $60 \%$ of total grain weight. Starch consists of 2 polymers, amylose and amylopectin. Amylose is a linear polymer made up of glucose molecules linked via $\alpha-(1-4)$ glucosidic bonds. Amylopectin is the larger polymer with $\alpha-(1-4)$ glucosidic and $\alpha-(1-6)$ glucosidic linkages, which form the branched structure (Hough 1985). The ratio of amylopectin to amylose is around 3:1 (Palmer 1983). Both amylose and amylopectin polymers are present in the barley endosperm starch granules. The large granules, designated A type, are round in shape and contain $70-80 \%$ amylose. The small, spherical, B type granules, contain $40-80 \%$ amylose (May and Buttrose 1959; Evers et al. 1999).

During malting, limited starch breakdown occurs, although Allosio-Ouarnier et al. (2000) reported increased levels of maltose, maltotriose, and maltotetraose during germination. Starch is degraded more during mashing by the hydrolytic enzymes $\alpha$-amylase, $\beta$-amylase, $\alpha$-glucosidase, and limit dextrinase. High temperature infusion mashes readily solubilise the starch but limit the activity of thermolabile enzymes, in particular $\alpha$-glucosidase and $\beta$-amylase (Osman et al. 1996a). Oliveira et al. (1994) related the effect of starch properties, namely granule volume and size, to hot water extract. Recently, the gelatinisation properties of starch were reviewed by Evers et al. (1999). For barley, gelatinisation temperature plays an important role in the quality of malt and hot water extract. The temperature at which gelatinisation occurs varies between 55 and $65^{\circ} \mathrm{C}$. MacGregor et al. (2002) presented data on the effects of gelatinisation temperature on normal, high, low, and zero amylose starches. Each starch type was found to vary, with the high amylose and waxy starches having gelatinisation temperatures higher than that for the normal starch, whereas high amylose starch showed a high level of resistance to enzymic attack in a slow ramp mash. Ellis et al. (1979) had previously demonstrated that high amylose barley had an increased gelatinsation temperature. 
In 'waxy' barley, the amount of amylopectin increases to $>90 \%$ (Evers et al. 1999). However, waxy barleys generally have lower hot water extract values, and higher $\beta$-glucan content and cell wall modification levels (Ullrich et al. 1986; Swanston 1996). These factors complicate any interpretation of the impact of changes on starch properties. The main requirement seems to be for a high level of starch, which is not lost during malting and is readily convertible to fermentable sugars in the brewery (low gelatinisation temperature).

\section{Non starch polysaccharides}

The major constituent of barley endosperm cell walls are $\beta$-D-(1-3), (1-4) glucans (75\%), with a minor component identified as arabinoxylans (20\%) (Fincher 1975; Fincher and Stone 1986; Henry 1987). The arabinoxylan fraction is usually referred to as pentosan. The solubility of $\beta$-glucan in beer varies according to the number and arrangement of (1-3) and (1-4) linkages (Izawa et al. 1993) as well as the size of the molecules. The range in barley for $\beta$-glucan is and $2-10 \%$ of total grain weight (Henry 1987). Both genotype and environment influence the content of $\beta$-glucan.

Recent studies have presented models of the structure of endosperm cell walls. Autio et al. (1996) suggested that the cell walls of the endosperm have a layered structure. Bamforth and Kanauchi (2001) presented a model whereby the outer cell wall was made up of xylan, arabinose, and ferulic and acetic acids, with the inner layer composed of $\beta$-glucan. These results indicate that enzymic hydrolysis of the arabinoxylan layer would be critical to ensure that $\beta$-glucanase could hydrolyse the $\beta$-glucan layer. Vietor et al. (1991) and Han and Schwartz (1996) reported that arabinoxylan survives into malt and beer, albeit in smaller oligosaccharide forms. Similarly, it was shown that xylanases could release all pentosan as well as limited amount of $\beta$-glucan from cell walls (Kanauchi and Bamforth 2002). During germination or malting, the 'modification' of the endosperm relates to the breakdown of the cell wall and endosperm components. Although endosperm modification is measured through the solubilisation of endosperm protein reserves, access to those reserves is only possible after cell wall breakdown. Henry (1987) measured the breakdown of $\beta$-glucan during malting. The results indicated that by day 4 of germination, barley $\beta$-glucan had decrease from $5 \%$ to around 1\%. Similarily, Allosio-Ouarnier et al. (2000) reported increased level of sugars derived from $\beta$-glucan and arabinoxylan components during malting. Although these studies analysed the complete malting process, Walker et al. (2001) suggested that by day 2 of germination, the $\beta$-glucan level could be used to indicate if a variety had desirable extract potential. Stewart et al. $(1998,2000)$ demonstrated that both $\beta$-glucan and pentosan impact on wort viscosity and beer filtration rates. Thus, the enzymic breakdown of $\beta$-glucan and pentosan during malting is critical for efficient brewing. Mashing temperature has an influence on the solubility of $\beta$-glucan. Palmer and Agu (1999) demonstrated the difference in solubility of $\beta$-glucan when malt was mashed at $45^{\circ} \mathrm{C}$ or $65^{\circ} \mathrm{C}$, with an increased level of solubilisation at the latter temperature.

The level of $\beta$-glucan has been shown to have a relationship with other malt quality traits. Importantly, high $\beta$-glucan levels may not result in higher or lower extract but relate to other malt quality traits such as Kolbach Index (ratio of soluble to total protein), viscosity or the speed of filtration (Evans et al. 1999). Views differ on the relationship between $\beta$-glucan and foam stability Lusk et al. (2001).

\section{Physiological grain traits}

Grain size

Grain size is an important descriptive trait based on the physiology of the grain. The final grain size is determined by several environmental effects as well as biochemical components within the grain itself (Coventry et al. 2003b). For thousands of years when grain was used specifically for human consumption, it has been selected based on size. Within the last century, barley breeders have continued to target large grain genotypes in association with improved yield and other attributes. In Australia, the measurement of grain size is generally based on 4 fractions: $<2.2 \mathrm{~mm}$ (screenings), $>2.2 \mathrm{~mm},>2.5 \mathrm{~mm}$, and $>2.8 \mathrm{~mm}$. Industry standards on plump grain are based on the total of the 2 largest grain fractions. Smaller grain generally has lower starch and higher protein levels, thus reducing the extract potential. Large grains generally have increased levels of starch and therefore more potential extract. However, excessively large grain could impact on malt quality particularly on the rate of water hydration and modification during malting. Australian barley breeders have used Triumph and related progeny carrying the $s d w 1$ semi-dwarf gene extensively to gain improvement in malt extract. It has proved difficult to recover plump-grained semi-dwarf progeny as the $s d w l$ gene is associated with small grain size.

\section{Dormancy}

Dormancy is not a biochemical component like starch or protein that can be isolated and measured from grain, but an understanding of the level of dormancy in barley is critical in terms of malt quality. Malting barley is one of the few grains where the seed is required to germinate for product development, ie. production of malt. The failure of barley grain to germinate at an acceptable level, i.e. $>95 \%$, could introduce problems during the malting process.

The physiological and biochemical components of dormancy may be as complex as grain yield. Romagosa et al. (1999) and Li et al. (2003) reported on some of the genetic associations of dormancy. The role of hormones and enzymes in dormancy has been documented in recent 
reviews by Briggs and Woods (1993) and Benech-Arnold (2002), the latter author describing the most significant and relevant aspects of dormancy and pre-harvest sprouting. Several biochemical mechanisms have been associated with dormancy, including an antagonistic effect between abscisic acid (ABA) and gibberellic acid (GA). For example, Weidner et al. (1993) demonstrated a relationship between phenolic acids and barley dormancy with an increase in total and free phenolic acid content coinciding with the pattern of dormancy after flowering and post ripening. In addition it was demonstrated that ferulic and sinapic acid retarded germination of ripening barley embryos, and Wang et al. (1995) showed that an increased level of hydrogen peroxide reduced the inhibitory effect of ABA. The biochemistry of dormancy is complex and covered in a large and diverse literature.

\section{Grain hardness (milling energy)}

Grain hardness is a trait not routinely measured when evaluating barley grain quality. Hardness would normally be considered in terms of wheat quality whereby hardness describes the texture of the grain endosperm. Starch granules are either readily separated from the protein matrix (soft) or else the granules resist separation (hard). In general, malting barley varieties can be classified as soft, whereas non-malting or feed varieties are classified as hard (Alison et al. 1976). Hardness has also been associated with the level of modification of malt, which would imply that grain components within the endosperm directly affect modification. Specific proteins that interact with starch granules such as hordoindolines, including friabilin, have also been implicated in grain hardness (Darlington et al. 2000).

Milling energy has been used as a measure of barley grain hardness. Finished malt may be analysed either for milling energy or for 'friability', thereby providing an indication of malt endosperm modification. Recent studies have demonstrated the relationships between barley hardness (milling energy) and grain and malt quality parameters (Swanston et al. 1995). Grain protein and $\beta$-glucan have been positively correlated with hardness (Henry and Cowe 1990), and malt extract and endosperm modification correlated negatively to hardness (Swanston and Taylor 1988; Swanston et al. 1995). B and $\mathrm{C}$ hordein have been shown to be associated with milling energy, where an increase in $\mathrm{C}$ hordein along with a decrease in $\beta$-glucan corresponded to a decrease in milling energy. The reverse was reported for B hordein, although that study was conducted with a limited dataset (Molina-Cano et al. 1995). The effects of environmental impacts on grain components such as $\beta$-glucan and protein have been associated with changes in milling energy (Henry 1985; Swanston and Cowe 1989, Henry and Cowe 1990).

\section{Malt quality}

Alpha-amylase

$\alpha$-Amylase (EC 3.2.1.1) is an endohydrolase that randomly cleaves $\alpha-(1-4)$ glucosidic bonds in starch. The level of this enzyme is not usually detectable in barley but increases once germination commences (Bathgate and Palmer 1973). In most cereals, the $\alpha$-amylase I (Amy2) form appears shortly after anthesis. The level declines during grain maturation. When germination commences, a second form, $\alpha$-amylase II (Amyl), appears. In the first hours of germination, $\alpha$-amylase II is released from the scutellum. After the first day of germination, the aleurone becomes the main source of $\alpha$-amylase (Munck et al. 1981). The level of $\alpha$-amylase II formation is highly dependent upon GA (Freeman 1984). In the presence of GA, both enzyme groups continue to be secreted by the aleurone (MacGregor 1987). Multiple forms of amylase I and II exist and these forms can vary between varieties (MacGregor 1987).

A third form of $\alpha$-amylase (III) has been reported. It is a complex between amylase II and an amylase inhibitor protein (MacGregor 1987). However, recent evidence on the location of expression of the inhibitor gene suggests that the binding of this inhibitor to $\alpha$-amylase is probably not significant in vivo (Furtado et al. 2003)

The $\mathrm{pH}$ optimum for $\alpha$-amylase is below mashing $\mathrm{pH}$. $\alpha$-Amylase II is highly dependent upon the level of calcium ions present. During mashing, the enzyme was shown to be highly active, although several variables influenced the total activity. The optimal temperature for $\alpha$-amylase II is around $65^{\circ} \mathrm{C}$ (Briggs et al. 1981; Hoseney 1986), which would allow the enzyme to perform efficiently under most mashing conditions. However, consideration has been given to improving its thermostability in barley by introduction of a novel genetic form of the enzyme from bacteria (Vickers et al. 1996). Preliminary results suggested that mashing could be carried out at temperatures as high as $75^{\circ} \mathrm{C}$. In a $65^{\circ} \mathrm{C}$ infusion mash, the activity of the bacterial enzyme was found to be 1.5 times that of the barley enzyme (Vickers et al. 1996).

\section{Beta-amylase}

$\beta$-Amylase (EC 3.2.1.2) is one of the key enzymes involved in the production of the fermentable sugar, maltose, which is utilised by yeast during fermentation. This enzyme is found in mature grain in 2 forms, free and bound. $\beta$-Amylase is a multi-genic locus (Bamy1, Bamy3) (Li et al. 2002). While not a true storage protein, $\beta$-amylase has been associated with hordeins and other proteins in the endosperm (Broadbent and Palmer 2001). The level of grain protein has an impact on the level of $\beta$-amylase. For example, increased levels of nitrogen nutrition resulted in elevated levels of $\beta$-amylase. However, higher levels of $\beta$-amylase in the grain do not necessarily result in equally high levels of $\beta$-amylase 
in the malt (Broadbent and Palmer 2001). $\beta$-Amylase is also found in a bound form as a hetero-dimer with protein $\mathrm{Z}$. The activation of the $\beta$-amylase is mediated through cleavage with the malt endopeptidase (Mep1) (Guerin et al. 1992). An alternative view is that the bound form is linked to the hordein matrix, and results suggest that the bound form was released by proteinase activity during germination (Grimes and Briggs 1995; Buttimer and Briggs 2000a, 2000b). A cellular $\mathrm{pH}$ of 5.3 is optimal for the enzyme. However, conditions during mashing of $\mathrm{pH}>6.0$ are not optimal and impact significantly on its action in commercial mashes.

$\beta$-Amylase is an exoenzyme that cleaves the disaccharide maltose from the non-reducing end of amylose and amylopectin. The enzyme activity alone catalyses the hydrolysis of $\sim 70 \%$ of the amylose and $50 \%$ of the amylopectin fractions of barley starch (Hoseney 1986). The stability of $\beta$-amylase decreases rapidly at temperatures $>55^{\circ} \mathrm{C}$ (Hoseney 1986). For decoction style mashes (a low initial mash-in temperature followed by rapid heating), $\beta$-amylase remains active until the mash temperature exceeds $55^{\circ} \mathrm{C}$. In comparison, for a mashing style where the infusion temperature is $>65^{\circ} \mathrm{C}$, the activity of $\beta$-amylase is reduced in a few minutes. Fix (1989) has shown that in high temperature mashes, with a low grist:liquor ratio, the maltose level is higher in the final wort. This suggests substrate protection of the enzyme within a thick mash. Two major forms ( $\mathrm{Sd} 1$ and $\mathrm{Sd} 2$ ) have been observed in commercial barley varieties. Sd2 was shown to have higher thermosablity, and a third form ( $\mathrm{Sd} 3$ ) with increased thermostability was identified in Hordeum spontaneum (Eglinton et al. 1998; Kihari et al. 1998). This enzyme has been shown to remain active at temperatures $>60^{\circ} \mathrm{C}$ under simulated commercial mashing conditions. Additionally, Kaneko et al. (2000) and Swanston and Molina-Cano (2001) have also demonstrated variation in the thermostability of $\beta$-amylase between barley varieties. The $\beta$-amylase allele not only determines the level of thermostability but also determines the level of free and bound, with Sdl exhibiting an higher level of binding than $\mathrm{Sd} 2$ (Li et al. 2002).

\section{Limit dextrinase}

Limit dextrinase (EC 3.2.1.41) catalyses the hydrolysis the $\alpha-(1-6)$ glucosidic linkages of amylopectin. The enzyme produces an increased number of smaller linear oligosaccharide chains that are subsequently rapidly hydrolysed by $\alpha$-amylase and $\beta$-amylase. Limit dextrinase $(L d x)$ has been detected in, and extracted from, ungerminated barley (Manners and Yellowlees 1973; Yamada 1981; Lenior et al. 1984; Sissons et al. 1993; McCleary 1992). However, its level increases during germination, with maximum activity obtained after 8 days. The same structural gene produces the enzyme found in both developing grain and germinating grain (Burton et al. 1999; Li et al. 1999b). The observed increase in total limit dextrinase activity is due to a bound form being released by the action of proteinase (Longstaff and Bryce 1993; Sissons et al. 1994). Purified limit dextrinase has been found to have an optimal $\mathrm{pH}$ of 5.5 and temperature of $50^{\circ} \mathrm{C}$ (Sissons et al. 1992a). ELISA methods developed from purified enzyme have been used to study limit dextrinase activity (Sissons et al. 1992b). Stenholm and Home (1999) have shown that malt limit dextrinase, under programmed mashing conditions, has a similar $\mathrm{pH}$ optimum but higher temperature optimum of $60-63^{\circ} \mathrm{C}$. These results have been confirmed by Osman et al. (1996b). Malt limit dextrinase has been observed to have a positive influence on wort fermentability. This is presumably due to an increase in the production of linear oligosaccharides, allowing $\alpha$ - and $\beta$-amylase to carry out their functions (Stenholm and Home 1999). Limit dextrinase inhibitors are also proposed to play a role in malt quality (MacGregor et al. 2002)

\section{Alpha-glucosidase}

$\alpha$-Glucosidase (EC 3.2.1.20) is the fourth enzymic activity involved in hydrolysis of starch during mashing. The enzyme catalyses the release of glucose from maltose and higher sugars. Like $\alpha$-amylase, $\alpha$-glucosidase is synthesised during germination and dependent upon GA. The role of $\alpha$-glucosidase in malting and mashing has not been clearly defined. Agu and Palmer (1997) reported an increase in the level of $\alpha$-glucosidase and also in glucose levels during malting. Osman et al. (1996a) demonstrated that $\alpha$-glucosidase hydrolyses oligosaccharides preferentially over starch polymers. This suggests that $\alpha$-glucosidase would rely on the availability of oligosaccharide substrates released by the prior action of the other 3 starch-degrading enzymes. The $\mathrm{pH}$ optimum for $\alpha$-glucosidase appears to depend upon substrate: 4.5-4.6 for maltose substrate but 5.0 for starch as a substrate (Osman et al. 1996a; Agu and Palmer 1997). Under mashing conditions, $\alpha$-glucosidase activity is reduced, suggesting that activity would be limited during mashing and dependent upon the activity of $\alpha$ - and $\beta$-amylases (Osman et al. 1996a). The amount of $\alpha$-glucosidase activity present in a hot water extract was found to be considerably lower than the activity of other starch-degrading enzymes (Osman et al. 1996b). Overall, the efficiency of $\alpha$-glucosidase during mashing is dependent upon temperature, $\mathrm{pH}$, and the availability and form of substrate (Osman et al. 1996a, 1996b; Agu and Palmer 1997).

\section{Beta-glucanase}

$\beta$-(1-3), (1-4)-Glucan-4-glucanhydrolases (EC 3.2.1.73) or $\beta$-glucanase has received considerable attention by researchers over the past 50 years. The function of $\beta$-glucanase is to hydrolyse $\beta$-glucan during germination. Two isoenzymes, EI (Glbl) and EII (Glb2), have been identified and their functional properties reported 
(Woodward and Fincher 1982). $\beta$-Glucanase is produced during grain germination in the aleurone and scutella, with EII and EI produced in the aleurone and EI produced from the scutella (Stuart et al. 1988). The level of the EII enzyme increases upon the addition of GA.

The first stage of endosperm modification is the breakdown of cell walls. This is one of the critical steps in producing good quality malt. The hydrolysis of $\beta$-glucan during germination has a significant impact on the final malt quality. The mechanism and enzymes involved in cell wall modification remain somewhat unclear. However, it is clear that an increase in malt $\beta$-glucanase levels results in reduced levels of $\beta$-glucan in wort. Slow and/or incomplete breakdown of barley $\beta$-glucan has been shown to have a negative impact on hot water extract (Henry 1986; Stuart et al. 1988), as well as causing viscosity and filtration problems in the brewhouse (Stewart et al. 1998, 2000).

$\beta$-Glucanase, as with most enzymes in cereals, is inactivated at high temperatures. Woodward and Fincher (1982) reported the optimal temperatures for EI and EII to be $\sim 37^{\circ} \mathrm{C}$ and $45^{\circ} \mathrm{C}$, respectively. $\beta$-Glucanase activity is considerably reduced during the kilning process, and in the initial stages of high temperature mashing (Woodward and Fincher 1982; Loi et al. 1988). All activity is lost after $\sim 15$ min under these conditions. Hence, commercial brewing requires either high levels of $\beta$-glucanase or an increase in thermostability of the existing enzymes.

$\beta$-Glucan hydrolysis in malting and mashing still remains an important target in barley breeding programs. High levels of $\beta$-glucanase may be required for high temperature mash breweries or in breweries that use unmalted barley as an adjunct. The development of varieties processing high levels of $\beta$-glucanase or increased thermostabilities will remain an important breeding target.

\section{Proteinases}

Protein breakdown during malting has not received as much attention as that of the carbohydrates. The influence of storage protein within the grain, its subsequent degradation during malting and brewing, the function of proteinases, exopeptidases, and carboxypeptidases, and the influence of these factors on malt and beer quality has been recently reviewed (Wallace and Lance 1988). The mechanisms and control of the breakdown of storage proteins have only been partially unravelled. Early studies were limited to general proteinase activity. More recently, assays have been developed that can more precisely describe the specificity of individual proteinases under germination or mashing $\mathrm{pH}$ and temperature optima.

Four classes of proteinases (cysteine, serine, aspartic, and metallo) have been identified in barley. The most abundant are the cysteine enzymes (Zhang and Jones 1995a, 1995b; Zhang and Jones 1999). Studies on individual proteinase classes have been limited while the roles of the various classes have not yet been clearly defined. Jones and co-workers have carried out several studies attempting to characterise the role of these enzymes during malting and mashing (Poulle and Jones 1988; Wrobel and Jones 1992a, 1993; Zhang and Jones 1995a, 1995b; Fontanini and Jones 2001; Jones and Marinac 2002). Most of the work previously reported used non-barley protein substrates. In contrast, Osman et al. (2002) characterised the major endoproteinase activities in malted barley using isolated native substrates, specifically hordein, and glutelin. These activities were all found to be of the cysteine class. The temperature optimum for endoproteinases with glutelin and hordein substrates was $50^{\circ} \mathrm{C}$ and $40^{\circ} \mathrm{C}$, respectively. Osman et al. (2002) further investigated the proteinase activity in a range of genotypes, although the differences between genotypes have not been established.

\section{Secondary traits (traits derived/influenced by processing)}

Some of the most important traits in terms of malt quality are expressed only during processing. However, most of these vary depending upon the conditions. The final result is highly dependent upon the above primary traits.

\section{Hot water extract}

The hot water extract of wort, commonly called malt extract (ME), is the most important trait whether selecting potential new malting varieties or trading malt. The quality of the extract is influenced by several factors (for a detailed review see Collins et al. 2003). The first is environmental, such as growing conditions, temperature, fertiliser, available nitrogen, or moisture. These factors do not impact on extract directly but rather affect traits that influence extract, particularly protein and starch levels and composition. The second is several genetic biochemical components that influence the final level of extract. These include 2- or 6-row types, husk thickness, grain size, protein, starch, non-starch polysaccharides, and enzyme production.

The third factor that influences extract is the malting process itself Axcell (1998) outlined the effects of malting on final beer quality. Most aspects of grain modification affect final beer quality, including important aspects such as clarity and foam stability. During malting, enzymes that have an impact on the degradation of substrates are either synthesised during germination or enzymically cleaved from their bound forms. The range of enzymes produced included those that degrade cell wall components, proteins, and starch. The process of malt production varies between countries, with 4-day germination schedules in Australia and 5-6-day germination schedules in many other countries. The objective for most maltsters is to maintain high extract levels and yet somehow achieve relatively low protein modification levels $(<50 \%)$ and low malting losses. 
Mashing is the fourth factor that influences extract. Within the mashing process, there are several physical factors that affect the resultant extract. These are $\mathrm{pH}$, mash time, mash temperature, grist/particle size, and grist to liquor ratio. Cook (1962) and Briggs et al. (1981) presented reviews, detailing the previous, and at the time, the current knowledge and technology on mashing.

Several studies have presented results detailing the relationship between grain and malt physical attributes and extract. Some of these attributes include protein levels and type of protein fractions (Smith 1990; Howard et al. 1996; Brennan et al. 1998; Molina-Cano et al. 2001), hardness and milling energy (Ellis et al. 1979; Alison 1986; Swanston and Taylor 1988), starch properties (Glennie-Holmes 1995a, $1995 b, 1995 c, 1995 d$ ), non-starch polysaccharides (Henry 1985; Molina-Cano et al. (1995), and husk thickness (Roumeliotis et al. 1999). The specifics of the relationships between extract and these attributes are outlined above.

\section{Diastatic power}

Diastatic power is the term used to describe the collective activity of starch degrading enzymes in malt. All 4 enzymes described above, $\alpha$-amylase, $\beta$-amylase, limit dextrinase, and $\alpha$-glucosidase, have been identified as being active during malting and mashing (Osman et al. 1996a). Industry methods used to measure diastatic power vary considerably in several aspects including substrate, $\mathrm{pH}$, and assay temperature. These variations may affect one or more of these enzymes. Most methods provide data solely on the enzyme potential under those conditions, which are far removed from industrial mashing conditions (Henry 1984). The value of diastatic power as currently measured in assessing barley quality in industry or breeding is questionable.

\section{Wort viscosity}

The importance of low levels of wort viscosity has increased with the introduction of membrane filtration in breweries. High levels of viscosity reduce the efficiency of breweries. Viscosity, like hot water extract, cannot be related to a single trait within barley. The breakdown of $\beta$-glucan during malting has been shown to have a direct impact on extract viscosity in high temperature infusion mashing. High molecular weight fractions have been implicated as one of the main components in increasing wort viscosity. However, the methods used to measure $\beta$-glucan vary. Hence, direct comparison cannot be made between viscosity and any of the various $\beta$-glucan fractions. Other barley cell wall polysaccharides (arabinoxylan) have been demonstrated to have an impact on viscosity and, thereby, beer filtration (Stewart et al. 1998, 2000).

\section{Feed barley quality traits}

The major portion of the Australian barley grain crop received as feed (around 50\%) is used as domestic feed grain
(Hafi and Rodriguez 2000). The remainder is exported. Domestic feed barley is made up of a combination of poor quality malting varieties and specific feed varieties. Over $60 \%$ of the feed barley is used by the beef and dairy cattle industries in Australia (ALFA 2001). Overall, feed varieties are those that either do not the pass industry malt quality standards (MBIBTC 1995) or were bred for improved agronomic performance. These are simply designated as feed varieties, not necessarily possessing desirable feed quality attributes. This section has focused on hulled varieties, as these comprise most of the barley production used in animal production in Australia. However, we acknowledge that hulless barleys are finding increased usage for monogastrics (Ullrich 2002).

Current understanding of true feed quality is somewhat limited. However, a recent review indicates that several grain traits in barley are relevant to feed quality. Several reviews have listed many traits that could be related to feed quality, including a high starch level, low protein, acid detergent fibre (ADF), and neutral detergent fibre (NDF) (Overnell-Roy et al. 1998a, 1998b, 1998c; Ullrich 2002). A special edition of the Australia Journal of Agricultural Research (Vol. 50, issue 5, 1999) comprised a comprehensive set of reviews on the current knowledge of feed quality. Areas covered were grain composition and attributes that contribute to feed quality. These included both processing (Rowe et al. 1999; Kaiser 1999) and analytical methodology (Petterson et al. 1999; Wrigley 1999). The general consensus was that there were critical differences between grain types and feed quality, which have an effect on animal performance (both ruminants and monogastrics).

Starch, protein, and fibre (ADF and NDF) are the main grain attributes in barley that have a direct impact on feed potential. All of these traits are influenced by both genotype and environment. Thus, it can be assumed possible to genetically select for feed quality. However, from a breeding perspective it is still unclear as to the definitive range of values for grain traits that would have a direct and positive influence on animal performance. To date, only one 'feed' quality variety (Valier) has been released with claims of a direct improvement in animal performance over the parent varieties (Boss et al. 1999). Particle size, ADF, starch, as well as rate and extent of fermentation were considered to be the most significant factors influencing performance (Bowman et al. 1996).

Within the malting industry, processing of the grain has a direct impact on malt and beer quality. Similarly, processing of grain in the feed industry would also appear to impact on feed quality. Barley hardness is proposed to be associated with feed grain quality. Bowman et al. (1996) reported a negative correlation between particle size index (hardness) and ADF or dry matter digestibility (DMD), but a positive correlation to daily liveweight gain. Rowe et al. (1999) also found that particle size has a direct impact on animal 
performance. In addition, treatment of the grain via heating or cooking has been found to have a positive effect on animal performance, as well as the use of supplements.

Limited data have been published on the relationship between feed and malt quality. Crosbie and Portman (1977) reported on the relationships between European Brewery Convention (EBC) style malt extract and fibre. Significant $(P<0.05)$ negative correlations were obtained between extract and both ADF and NDF. Further analysis is required on well-designed sample sets to define the relationships between barley traits for malt and feed quality. These, in turn, would be useful for breeding programs to select for feed quality varieties. It has been proposed to use the EBC extract as an indicator of feed quality (Molino-Cano et al. 1997) in a combined feed/malt quality testing program within a barley breeding program (P. A. Inkerman and G. P. Fox, unpublished data)

Overall, the feed industry has yet to define quality in terms of meanful parameters that can be used for improved breeding selection. Until then, feed varieties will remain second-class quality grain.

\section{Genotype and environmental interactions and malting quality traits}

Environmental conditions, predominantly as a result of variation in temperature and available soil moisture, are known to have a significant effect on barley quality. In general, a combination of these factors affects the rate and duration of grain filling and ultimately impacts on the percentage of starch in the grain. Starch is the most abundant component in barley by weight (Henry 1988). Under high temperature conditions, its synthesis is diminished (Bhullar and Jenner 1996), and therefore lower starch content will be associated with malt extract potential.

In addition to environmental effects, the interaction between genotype and environment contributes to the often-unpredictable variation that describes the collective quantitative traits known as malting quality. The unpredictable contribution of environmental effects is a major concern to the barley industry, as barley is often deemed of acceptable quality if the cultivar meets certain grain specifications (kernel weight, percentage screenings and protein content); however, these measurements only partially explain the potential malting quality.

The rate and duration of grain filling (Savin and Nicolas 1999) affects the final weight and composition of the barley kernel. Other factors such as ambient temperatures and the timing of the occurrence of above-optimal temperatures at critical stages of grain development can induce stress effects altering metabolic enzyme activity (MacLeod and Duffus 1988) and have an effect on malting quality. The optimal temperature for maximum kernel weight in cereals ranges from 15 to $18^{\circ} \mathrm{C}$ (Chowdhury and Wardlaw 1978). For each increase of $1^{\circ} \mathrm{C}$ between 24 and $30^{\circ} \mathrm{C}$, Wardlaw et al. (1989) demonstrated a decrease of 3-4\% in kernel weight. In most areas that grow barley, ambient temperatures often exceed $30^{\circ} \mathrm{C}$ during grain filling, and above-optimal temperatures $\left(>35^{\circ} \mathrm{C}\right)$ for short periods during the day are common. These very high ambient temperatures have been associated with plant stress, as water deficit within the plant often occurs concomitantly, particularly under dryland farming. Under such conditions the temperature of the plant may exceed the ambient temperature by up to $5^{\circ} \mathrm{C}$ (Panozzo et al. 1999), due to a reduced rate of transpiration as the plant minimises moisture loss.

The effect of short periods of high temperatures during the mid-stages of grain filling [20-25 days after anthesis (DAA)] is a reduction in the duration of grain filling (Savin et al. 1997; Wallwork et al. 1998a), leading to reduced grain yield associated with a reduction in kernel weight and an increase in screenings due to a reduction in the duration of starch synthesis. While the supply of assimilates has been demonstrated to be non-limiting under conditions of high temperature, the conversion of sucrose to starch has been associated with reduced activity of sucrose synthase (Macleod and Duffus 1988). The reduction in starch content can be attributed to the reduced enzymic activity associated with the synthesis of amylose and amylopectin. Wallwork et al. (1998b) reported that high temperatures $\left(>35^{\circ} \mathrm{C}\right)$ resulted in a reduced activity of the granule-bound starch synthase that is responsible for the synthesis of amylose and causes an immediate loss of activity for soluble starch synthase, which is involved in the synthesis of amylopectin. Izydorczyk et al. (2001) showed that growing environment had a significant $(P \leq 0.05)$ effect on amylopectin and amylose content and subsequent biochemical changes during germination.

The reduction in starch content at above optimal temperatures is also accompanied by a reduced endosperm volume, therefore decreasing the volume available for the accumulation of starch. Furthermore, high temperatures $\left(>35^{\circ} \mathrm{C}\right)$ can alter the relative proportions of A- and B-type starch granules in the endosperm (Savin et al. 1997). Under these conditions the reduced duration of grain filling resulted in a decrease in the volumetric percentage of A-type granules and increased the volumetric percentage of B-type granules. This change in the ratio of A- to B-type granules may alter the mashing quality during brewing, as A-type granules are more susceptible to hydrolysis by $\alpha$-amylase during mashing. In addition the digestion of the A-type starch granules by amylase is from within the granule, while for B-type granules, the $\alpha$-amylase initially attacks the surface of the granule (Macgregor and Balance 1980) and may also have an effect on the mashing quality.

While it can be demonstrated that total starch content and composition can be significantly affected by environmental conditions, it appears that protein percentage is less sensitive to high temperatures (Bhullar and Jenner 1996; Savin and 
Nicolas 1996). On a macro scale, environmental conditions can have a significant effect on protein percentage (Eagles et al. 1995; Zhang et al. 2001), often determining whether a barley cultivar will meet the grain receival standards. Grain buyers use protein percentage as the surrogate measure for malting quality, due to the inverse relationship with starch content and positive correlation with diastatic power. The total protein percentage does not take into account the influence of environmental conditions as the differential synthesis of B, C, and D hordein, which can have an effect on malt extract (Howard et al. 1996; Molina-Cano et al. 1995, 2000a, 2001, 2002).

$\beta$-Glucans are the main structural components of endosperm cell walls (Fincher 1975), forming a barrier for hydrolytic enzymes attacking starch and protein within the cell walls. The initiation of an efficient breakdown during germination and the completion during mashing is essential to optimise malt extract and minimise wort viscosity. Although $\beta$-glucan levels in barley are determined by genetic factors (Powell et al. 1985), environmental factors during grain filling have a significant effect (Morgan and Riggs 1981; Henry 1986 and Stuart et al. 1988). As $\beta$-glucans are synthesised early during grain filling, this period appears to be the critical time in determining the concentration that will be present in the mature grain. Macnicol et al. (1993) reported that water stress in a glasshouse experiment at 17 DAA led to a $24 \%$ decrease in $\beta$-glucan, whereas heat-stress had little or no effect on $\beta$-glucan. This has been confirmed by Perez-Vendrell et al. (1996), who reported that cool temperatures and high rainfall early in grain filling lead to a lower $\beta$-glucan content. Similarly, Wallwork et al. (1998a) also reported that $\beta$-glucan was not affected by the imposition of high daytime temperatures of up to $35^{\circ} \mathrm{C}$ from 18 to 20 DAA. Environmental factors have been reported to modulate hydrolytic enzymes such as $\beta$-glucanase and limit dextrinase, which are synthesised de novo during germination (Stuart et al. 1988; Arends et al. 1995). Kenn et al. (1993) have shown that cool temperatures with adequate rainfall during grain filling are conducive to the barley kernel synthesising higher levels of enzymes during malting than barley grown in environments that experienced water deficit conditions during grain filling.

Structural differences in barley are due to differential rates and duration of synthesis of grain components and result in visual differences in barley endosperm. These differences are sometimes referred to as barley having either a 'steely' or 'mealy' appearance. Steely grains are physically harder and have a glassy-vitreous appearance as the endosperm consists of more tightly packed starch granules than in mealy grains. Steely grains are also higher in $\beta$-glucan and protein concentrations, particularly gamma-hordein, than mealy grains, which reduces the rate of water uptake during malting, therefore affecting germination (Henry and Cowe 1990). This effect is exacerbated when there is a high concentration of steely endosperm in the proximal region (Chandra et al. 1999).

Barley malting quality is controlled by multiple genes with strong interaction with environments. The first systematic quantitative trait locus (QTL) mapping in barley was reported by Hayes et al. (1993), in which 62 QTLs underlying 8 traits were mapped. Since then, great efforts have been made to map QTLs for malting quality by 3 major groups around the world (North American Barley Genome Mapping Project, Australia National Barley Molecular Marker Program, and European group). The main results are summarised in Table 2, including malting quality traits, populations used to map the QTLs, and chromosomal locations of QTLs. Parts of these results have been previously reviewed by Kleinhofs and Han (2002).

While the location of QTLs for malting traits throughout the barley genome is constant, the effects of QTL alleles may vary depending on the degree of influence of environmental factors. The extent of the interaction between QTLs and environment $(\mathrm{QTL} \times \mathrm{E})$ may be the direct effect of environmental conditions during grain filling or the direct expression of a particular gene to an environmental stimulus. Hayes et al. (1993) concluded that malting quality traits in the Steptoe $\times$ Morex population were relatively free of environmental interaction effects, and with the exception of grain protein, interactions were limited to agronomic traits. Where a significant QTL $\times$ E was noted, this was due to a difference in magnitude rather than a change in rank of a phenomenon or could be explained as the interaction of minor genes with the environment. A study undertaken by Mather et al. (1997) demonstrated the importance of considering multiple environments when identifying QTLs in the Harrington $\times$ TR306 population. However, this study was also unable to partition the QTL $\times \mathrm{E}$ effects. Marquez-Cedillo et al. (2001) reported for a doubled haploid population derived from Harrington $\times$ Morex, significant QTL $\times$ E interactions for malt extract at 2 of the 8 environments for QTLs on chromosome $5(1 \mathrm{H})$.

Differences in the response of QTLs over a range of environments provide an opportunity for a plant breeder to select QTLs that consistently respond and develop a specific phenotype that is buffered against the unpredictable nature of environment factors.

\section{Genes influencing quality}

The biochemistry, physiology, and genetics of malting quality is extremely complex. The current status of known genes and their alleles influencing malting and feed quality have been reviewed (Smith 1951; Nilan 1964; Briggs 1978; Rassmuson 1985; Brown 1987; Søgaad and von WettsteinKnowles 1987; von Wettstein-Knowles 1992; MacGregor and Bhatty 1993; Ullrich 2002; Kleinhofs and Han 2002) and are summarised in Table 3. Further references can be found in various Barley Genetics Newsletters and 
Table 2. QTLs mapped for barley malting quality

\begin{tabular}{|c|c|c|c|c|}
\hline Traits & Populations & $\begin{array}{l}\text { Number } \\
\text { of QTLs }\end{array}$ & Chromosomes & References \\
\hline \multirow[t]{10}{*}{ Malt extract } & Blenheim/E224 & $3-7$ & $1 \mathrm{H}, 2 \mathrm{H}, 3 \mathrm{H}, 5 \mathrm{H}, 7 \mathrm{H}$ & Thomas et al. 1996 \\
\hline & Dicktoo/Morex & 2 & $2 \mathrm{H}, 5 \mathrm{H}$ & Oziel et al.1996 \\
\hline & Steptoe/Morex & 7 & $1 \mathrm{H}, 2 \mathrm{H}, 4 \mathrm{H}, 5 \mathrm{H}, 6 \mathrm{H}, 7 \mathrm{H}$ & Hayes et al. 1993 \\
\hline & Blenheim/Kym & 8 & $1 \mathrm{H}, 2 \mathrm{H}, 3 \mathrm{H}, 4 \mathrm{H}, 5 \mathrm{H}, 6 \mathrm{H}$ & Bezant et al. 1997 \\
\hline & Harrington/TR306 & 3 & $1 \mathrm{H}, 5 \mathrm{H}$ & Mather et al. 1997 \\
\hline & Harrington/Morex & 3 & $1 \mathrm{H}, 2 \mathrm{H}$ & Marquez-Cedillo et al. 2001 \\
\hline & Chebec/Harrington & 2 & $1 \mathrm{H}, 5 \mathrm{H}$ & Collins et al. 2001 \\
\hline & Galleon/Haruna Nijo & 1 & $2 \mathrm{H}$ & Collins et al. 2001 \\
\hline & Alexis/Sloop & 4 & $1 \mathrm{H}, 2 \mathrm{H}, 5 \mathrm{H}$ & Collins et al. 2001 \\
\hline & Amagi Nijo/WI2585 & 1 & $5 \mathrm{H}$ & ANBMM \\
\hline \multirow[t]{7}{*}{ Diastatic power } & Steptoe/Morex & 9 & $1 \mathrm{H}, 2 \mathrm{H}, 4 \mathrm{H}, 5 \mathrm{H}, 6 \mathrm{H}, 7 \mathrm{H}$ & Hayes et al. 1993 \\
\hline & Dicktoo/Morex & $2-3$ & $4 \mathrm{H}, 5 \mathrm{H}, 7 \mathrm{H}$ & Oziel et al. 1996 \\
\hline & Blenheim/E224 & 4 & $1 \mathrm{H}, 3 \mathrm{H}, 5 \mathrm{H}$ & Thomas et al. 1996 \\
\hline & Harrington/TR306 & 4 & $1 \mathrm{H}, 5 \mathrm{H}, 6 \mathrm{H}, 7 \mathrm{H}$ & Mather et al. 1997 \\
\hline & Harrington/Morex & 2 & $2 \mathrm{H}, 7 \mathrm{H}$ & Marquez-Cedillo et al. 2001 \\
\hline & Chebec/Harrington & 1 & $4 \mathrm{H}$ & ANBMM \\
\hline & Alexis/Sloop & 3 & $1 \mathrm{H}, 4 \mathrm{H}, 5 \mathrm{H}$ & Collins et al. 2001 \\
\hline \multirow{5}{*}{$\alpha$-Amylase } & Steptoe/Morex & 9 & $1 \mathrm{H}, 2 \mathrm{H}, 5 \mathrm{H}, 6 \mathrm{H}, 7 \mathrm{H}$ & Hayes et al. 1993 \\
\hline & Dicktoo/Morex & 2 & $5 \mathrm{H}, 7 \mathrm{H}$ & Oziel et al. 1996 \\
\hline & Harrington/Morex & 2 & $4 \mathrm{H}, 5 \mathrm{H}$ & Marquez-Cedillo et al. 2001 \\
\hline & Harrington/TR306 & 3 & $5 \mathrm{H}, 6 \mathrm{H}, 7 \mathrm{H}$ & Mather et al. 1997 \\
\hline & Alexis/Sloop & 3 & $1 \mathrm{H}, 4 \mathrm{H}, 5 \mathrm{H}$ & Collins et al. 2001 \\
\hline \multirow[t]{5}{*}{ Grain protein } & Blenheim/E224 & $1-5$ & $1 \mathrm{H}, 2 \mathrm{H}, 3 \mathrm{H}, 5 \mathrm{H}, 6 \mathrm{H}$ & Thomas et al. 1996 \\
\hline & Dicktoo/Morex & $2-3$ & $1 \mathrm{H}, 4 \mathrm{H}, 5 \mathrm{H}, 6 \mathrm{H}$ & Oziel et al. 1996 \\
\hline & Steptoe/Morex & 6 & $2 \mathrm{H}, 3 \mathrm{H}, 4 \mathrm{H}, 5 \mathrm{H}$ & Hayes et al. 1993 \\
\hline & Harrington/TR306 & 4 & $4 \mathrm{H}, 5 \mathrm{H}, 7 \mathrm{H}$ & Mather et al. 1997 \\
\hline & Harrington/Morex & 3 & $2 \mathrm{H}, 5 \mathrm{H}, 7 \mathrm{H}$ & Marquez-Cedillo et al. 2001 \\
\hline \multirow[t]{3}{*}{ Soluble protein } & Harrington/TR306 & 2 & $5 \mathrm{H}, 7 \mathrm{H}$ & Mather et al. 1997 \\
\hline & Harrington/Morex & 3 & $1 \mathrm{H}, 4 \mathrm{H}, 5 \mathrm{H}$ & Marquez-Cedillo et al. 2001 \\
\hline & Blenheim/E224 & 2 & $2 \mathrm{H}, 5 \mathrm{H}$ & Thomas et al. 1996 \\
\hline \multirow[t]{2}{*}{ Viscosity } & Harrington/TR306 & 3 & $5 \mathrm{H}, 6 \mathrm{H}, 7 \mathrm{H}$ & Mather et al. 1997 \\
\hline & Blenheim/E224 & 4 & $2 \mathrm{H}, 3 \mathrm{H}, 4 \mathrm{H}, 5 \mathrm{H}$ & Thomas et al. 1996 \\
\hline Milling energy & Blenheim/E224 & $3-5$ & $2 \mathrm{H}, 3 \mathrm{H}, 5 \mathrm{H}, 7 \mathrm{H}$ & Thomas et al. 1996 \\
\hline Wort $\beta$-glucan & Dicktoo/Morex & 1 & $5 \mathrm{H}$ & Oziel et al.1996 \\
\hline Malt $\beta$-glucan & Steptoe/Morex & 6 & $1 \mathrm{H}, 3 \mathrm{H}, 4 \mathrm{H}, 7 \mathrm{H}$ & Han et al. 1995 \\
\hline Grain $\beta$-glucan & Steptoe/Morex & 3 & $1 \mathrm{H}, 2 \mathrm{H}$ & Han et al. 1995 \\
\hline Starch granule traits & Steptoe/Morex & 3 & $2 \mathrm{H}, 4 \mathrm{H}, 5 \mathrm{H}$ & Borem et al. 1999 \\
\hline Fermentability & Derkado/B83-12/21/5 & 4 & $4 \mathrm{H}, 5 \mathrm{H}, 7 \mathrm{H}$ & Meyer et al. 2001 \\
\hline
\end{tabular}

International Barley Genetics Symposia. The discovery of genes in the past been through naturally occurring or induced mutations.

The identification of genes for malting and brewing traits has been the main target of efforts to map the barley genome. Feed grain quality traits have been a secondary focus for attempts to map quality related genes despite the higher proportion of barley used as a feed grain (Ullrich 2002). Many feed quality traits are also characters important in malting and brewing quality. For example, genes contributing to malt extract may also make a contribution to energy value in feed quality, and recently genes associated with whisky have been identified in mapping populations (Meyer et al. 2001). These genes important in whisky production extend beyond those important in production of malt for beer

Although various populations have been used by different groups, construction of consensus linkage maps makes it possible to compare the QTLs mapped in the different populations (Langridge et al. 1995; Qi et al. 1996). A Barley bin-map developed by Kleinhofs (http://barleygenomics. wsu.edu) provided an alternative tool to compare the QTLs mapped in different populations. Bin map locations for barley QTLs have been summarised by Hayes et al. (2001). Figure 1 summarises the chromosomal locations of known QTLs based on the consensus linkage maps. The QTLs for a wide range of traits are clustered in various chromosomal regions. This is the case especially for chromosomes $5 \mathrm{H}$ and 
Table 3. Barley genes, character or trait, and chromosomal location relating to malting quality barleys (after Sogaad and von Wettstein-Knowles 1987; von Wettstein-Knowles 1992; references loc. cit. and GrainGenes)

Where possible the recommended system for gene locus nomenclature has been used (see Franckowiak et al. 1996)

\begin{tabular}{|c|c|c|c|c|c|}
\hline $\begin{array}{l}\text { Gene locus } \\
\text { recommended }^{\mathrm{A}}\end{array}$ & $\begin{array}{l}\text { Gene } \\
\text { locus }\end{array}$ & Synonyms & Character or trait & Chrom. & H Chom. \\
\hline Adhl & Adh 1 & $\begin{array}{l}\text { Adh } 2 \\
\text { Adh-H1 }\end{array}$ & Alcohol dehydrogenase & 4 & $4 \mathrm{H}$ \\
\hline Adh 2 & Adh 2 & Adh 1 & Alcohol dehydrogenase & 4 & $4 \mathrm{H}$ \\
\hline$A d h 3$ & Adh 3 & & Alcohol dehydrogenase & 6 & $6 \mathrm{H}$ \\
\hline amol & amo 1 & & High amylose & 3 & $3 \mathrm{H}$ \\
\hline Amyl & Amy 1 & & $\alpha$-Amylase II & 6 & $6 \mathrm{H}$ \\
\hline Amy 2 & Amy 2 & & $\alpha$-Amylase I & 1 & $7 \mathrm{H}$ \\
\hline ant1 & ant-1 & & Anthocyaninless & 1 & $7 \mathrm{H}$ \\
\hline ant13 & ant -13 & & Regulatory gene; proanthocyaninless, catechin \& anthocyaninless & 6 & $6 \mathrm{H}$ \\
\hline ant17 & ant -17 & & Flavone-3-hydroxylase & 3 & $3 \mathrm{H}$ \\
\hline ant 22 & ant-22 & & Proanthocyaninless, catechin \& anthocyaninless & 1 & $7 \mathrm{H}$ \\
\hline$b l x 1$ & $b l$ & & White aleurone xenia & 4 & $4 \mathrm{H}$ \\
\hline blxz & $b l 2$ & & White aleurone & 1 & $7 \mathrm{H}$ \\
\hline$b l x 3$ & $b l 3$ & & White aleurone & 4 & $4 \mathrm{H}$ \\
\hline blx 5 & $b l 5$ & & White aleurone & 1 & $7 \mathrm{H}$ \\
\hline Bmyl & Bmy 1 & Bam 1 & $\beta$-Amylase & 4 & $4 \mathrm{HL}$ \\
\hline Bmy2 & Bmy 2 & & $\beta$-Amylase & 2 & $2 \mathrm{H}$ \\
\hline Bamy3 & & & $\beta$-Amylase ${ }^{\mathrm{B}}$ & 4 & $4 \mathrm{HL}$ \\
\hline Cepl & & & Cysteine endopeptidase $\mathrm{B}^{\mathrm{C}}$ & 3 & $3 \mathrm{H}$ \\
\hline Cmal & Cma I & $\mathrm{CMa}$ & CM-protein A (A hordein) & 1 & \\
\hline $\mathrm{Cmbl}$ & $\mathrm{Cmb} \mathrm{I}$ & $\mathrm{CMb}$ & CM-protein B (A hordein) & 4 & $4 \mathrm{H}$ \\
\hline $\mathrm{Cmcl}$ & $\mathrm{Cm}$ 1 & $\mathrm{CMc}$ & CM-protein C (A hordein) & 1 & \\
\hline Cmdl & Cmd 1 & $\mathrm{CMd}$ & CM-protein D (A hordein) & 4 & $4 \mathrm{H}$ \\
\hline Cmel & Cme 1 & $\mathrm{CMe}$ & CM-protein E (A hordein) & 3 & \\
\hline Cxpl & & & Carboxipeptidase & & \\
\hline Cxp3 & & & Carboxipeptidase III & 6 & $6 \mathrm{H}$ \\
\hline Dip & Dip & Amy & High diastatic power & & \\
\hline Enp & Enp & Enp 1 & Endopeptidase & & \\
\hline etw & etw & M-737 & Endosperm thin walls & & \\
\hline gal & gal & GA-less & Gibberellin $\left(\mathrm{GA}_{3}\right)$-less & & \\
\hline gai & $g a i$ & GA-ins & Gibberellin $\left(\mathrm{GA}_{3}\right)$-insensitive & 2 & $2 \mathrm{H}$ \\
\hline Glbl & & & $(1 \rightarrow 3,1 \rightarrow 4)-\beta$-glucan 4-glucanohydrolase $\mathrm{EI}^{\mathrm{D}}$ & 1 & $1 \mathrm{H}$ \\
\hline Glb2 & & & $(1 \rightarrow 3,1 \rightarrow 4)$ - $\beta$-glucan 4 -glucanohydrolase EII ${ }^{\mathrm{E}}$ & 1 & $7 \mathrm{HL}$ \\
\hline Glb31 & & & $(1 \rightarrow 3)-\beta$-glucan 3-glucanohydrolase $\mathrm{e}^{\mathrm{F}}$ & 3 & $3 \mathrm{HL}$ \\
\hline Glb32 & & & $(1 \rightarrow 3)$ - $\beta$-glucan 3 -glucanohydrolase $\mathrm{F}^{\mathrm{F}}$ & 3 & $3 \mathrm{HL}$ \\
\hline Glb33 & & & $(1 \rightarrow 3)$ - $\beta$-glucan 3 -glucanohydrolase ${ }^{\mathrm{F}}$ & 3 & $3 \mathrm{HL}$ \\
\hline Glb34 & & & $(1 \rightarrow 3)$ - $\beta$-glucan 3-glucanohydrolase $\mathrm{F}^{\mathrm{F}}$ & 3 & $3 \mathrm{HL}$ \\
\hline Glb35 & & & $(1 \rightarrow 3)$ - $\beta$-glucan 3-glucanohydrolase $\mathrm{F}^{\mathrm{F}}$ & 3 & $3 \mathrm{HL}$ \\
\hline Glb36 & & & $(1 \rightarrow 3)$ - $\beta$-glucan 3-glucanohydrolase $\mathrm{F}^{\mathrm{F}}$ & 3 & $3 \mathrm{HL}$ \\
\hline Glb37 & & & $(1 \rightarrow 3)$ - $\beta$-glucan 3 -glucanohydrolase $\mathrm{F}^{\mathrm{F}}$ & 3 & $3 \mathrm{HL}$ \\
\hline GluA & GluA & & $\sim 30 \mathrm{kDa}$ glutenin (prolamine syn. glutelin) & 5 & $1 \mathrm{H}$ \\
\hline GluB & GluB & & $\sim 55 \mathrm{kDa}$ glutenin (prolamine syn. glutelin) & 5 & $1 \mathrm{H}$ \\
\hline GluE & GluE & & $\sim 33.5 \mathrm{kDa}$ glutenin (prolamine syn. glutelin) & 5 & $1 \mathrm{H}$ \\
\hline GluF & GluF & & $\sim 34.5 \mathrm{kDa}$ glutenin (prolamine syn. glutelin) & 5 & $1 \mathrm{H}$ \\
\hline Horl & Hor 1 & & C hordeins & 5 & $1 \mathrm{H}$ \\
\hline Hor 2 & Hor 2 & & $\mathrm{~B}$ hordeins & 5 & $1 \mathrm{H}$ \\
\hline Hor 3 & Hor 3 & Glu-HI & D hordeins & 5 & $1 \mathrm{H}$ \\
\hline Hor 4 & Hor 4 & $H r d G$ & & 5 & $1 \mathrm{H}$ \\
\hline Hor 5 & Hor 5 & $\operatorname{HrdF}$ & & 5 & $1 \mathrm{H}$ \\
\hline Hth2 & & & $\beta$-Hordothionin ${ }^{\mathrm{C}, \mathrm{I}}$ & 5 & $1 \mathrm{H}$ \\
\hline Isal & Isal & & Inhibitor of subtilisin $\& \alpha$-amylase ${ }^{\mathrm{C}}$ & 2 & $2 \mathrm{H}$ \\
\hline Int-c & Int-c & $I / I^{h} / i, v^{\prime} 5^{\prime}$ & Infertile intermedium/fertile intermedium/deficiens & 4 & $4 \mathrm{H}$ \\
\hline$L d x$ & $L D$ & & Limit dextrinase $^{\mathrm{G}}$ & 1 & $7 \mathrm{H}$ \\
\hline Ltpl & & & Lipid transfer protein ${ }^{\mathrm{C}}$ & 7 & $5 \mathrm{H}$ \\
\hline Mepl & & & Malt endopeptidase $\mathrm{H}^{\mathrm{H}}$ & 3 & $3 \mathrm{HL}$ \\
\hline nud & $n$ & & Naked caryopsis & 1 & $7 \mathrm{H}$ \\
\hline Pazl & Pazl & & Protein $\mathrm{Z4}$ & 4 & $4 \mathrm{H}$ \\
\hline$s r h$ & $s$ & & Short rachilla hair & 7 & $5 \mathrm{H}$ \\
\hline Vull & $h e x-v$ & $\mathrm{v}$ & Hexadistichon (6-row) & 2 & $2 \mathrm{H}$ \\
\hline $\operatorname{wax}$ & $w x$ & glx & High amylopectin endosperm (waxy endosperm, starch synthase) & 1 & $7 \mathrm{H}$ \\
\hline
\end{tabular}

${ }^{\mathrm{A}}$ Franckowiak et al. (1996). ${ }^{\mathrm{B}} \mathrm{Li}$ et al. (2002). ${ }^{\mathrm{C}}$ Cannell et al. (1992). ${ }^{\mathrm{D}} \mathrm{MacLeod}$ et al. (1991). ${ }^{\mathrm{E}}$ Loi et al. (1988). ${ }^{\mathrm{F}} \mathrm{Li}$ et al. (1999b). ${ }^{\mathrm{G}} \mathrm{Li}$ et al. $(1999 a) .{ }^{\mathrm{H}} \mathrm{Guerin}$ et al. (1994). ${ }^{\mathrm{I}}$ Beecher et al. (2001) 


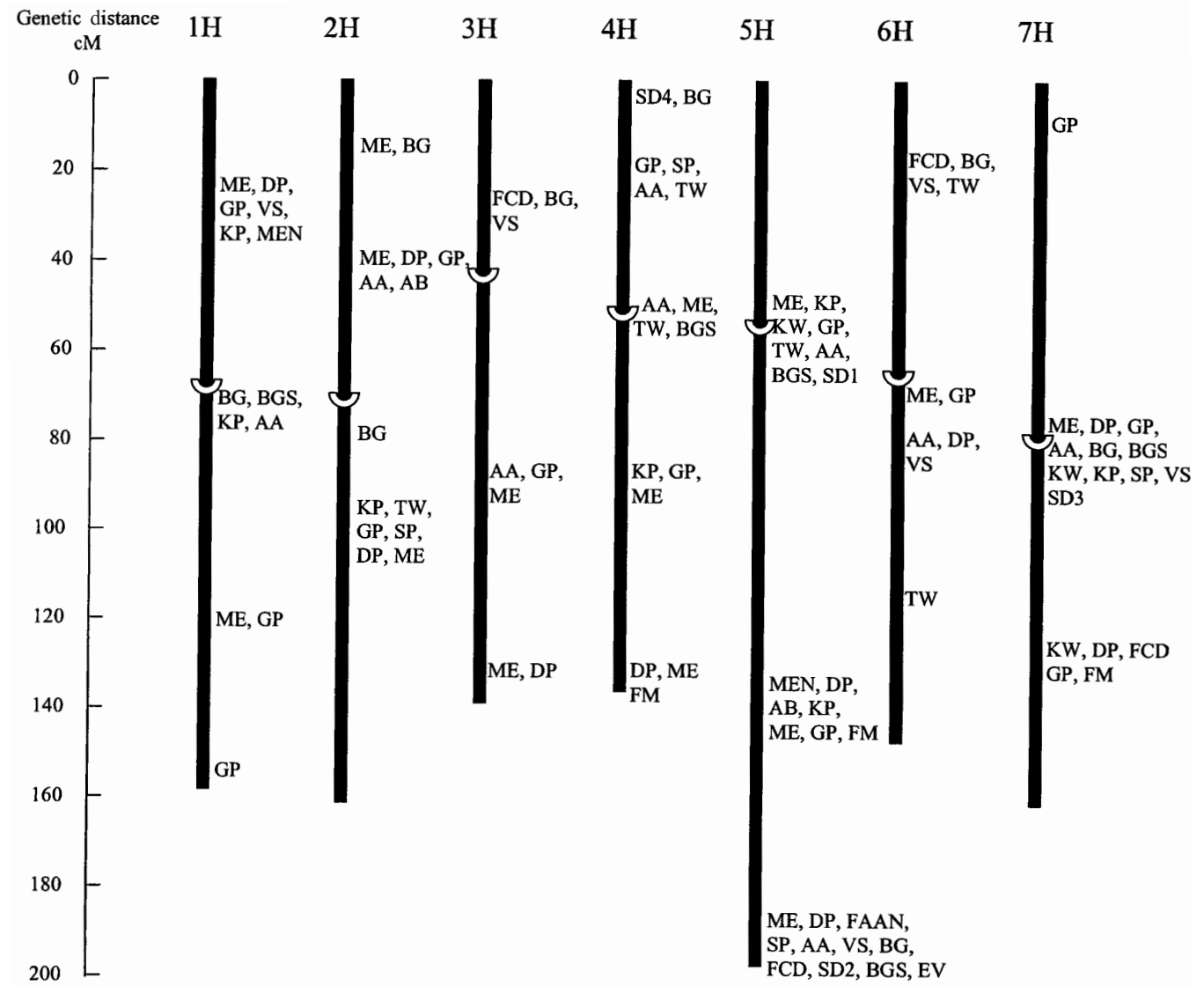

Fig. 1. Chromosomal locations of mapped QTLs controlling malting quality related to the barley consensus linkage map (Qi et al. 1996). AA, $\alpha$-amylase; AB, starch granule A/B; BG, $\beta$-glucan; BGS, $\beta$-glucanase; DP, diastatic power; EV, early vigor; FAAN, free amino acid nitrogen; FCD, fine-coarse difference; FM, fermentability; GP, grain protein; KP, kernel plumpness; ME, malt extract; MEN, milling energy; SD, seed dormancy; SP, soluble protein; TW, test weight; VS, wort viscosity.

$7 \mathrm{H}$ and may be due to multi-locus clusters, pleiotrophic effects, or reduced recombination in regions of the genome with increased marker density (Hayes et al. 1996). In term of breeding strategies, the net effect is that multiple phenotypes will be inherited as a unit. The availability of markers that define such key regions is of value in classifying germplasm and designing breeding strategies. For malting quality, this has both positive and negative effects. For example, the QTLs for high levels of enzyme activity, high diastatic power, and high malting extract were inherited as one unit, which will increase the breeding efficiency for improvement of malting quality. On the other hand, the QTLs for high grain nitrogen concentration were consistent with most QTLs for high levels of enzyme activity. The dwarfing gene (ari-e) on chromosome 5H was associated with high grain screenings, and reduced malting extract and fermentability (Meyer et al. 2001). Therefore, the application of this information in a breeding program requires further studies. Furthermore, as multiple QTLs were detected for each trait, the efficient selection of these QTLs at one time in a breeding program presents a difficult logical problem and raises further questions.

QTLs for a given trait have been detected in multiple mapping populations and environments. For example, several important malting quality QTLs are always detectable in the similar region of chromosome $5 \mathrm{H}$ in several experiments (Hayes et al. 1993; Han et al. 1995; Oziel et al. 1996; Tinker et al. 1996 Li et al. 2002, Paris et al. 2002). The QTL $\times$ environment interaction only results in differences in the magnitude of QTL effects. The molecular markers associated with these QTLs have great value as effective tools in marker-assisted selection for malting quality.

Functional gene loci have been found to make a large contribution to an associated QTL (Backes et al. 1995; Hayes et al. 1993; Li et al. 1999a, 2001; Oziel et al. 1996). These include Amyl on chromosome 6H, Bmyl on chromosome $4 \mathrm{H}, L D$ on chromosome $7 \mathrm{H}$, and Hor cluster on chromosome $1 \mathrm{H}$. The gene sequences can be used to develop perfect molecular markers for marker assisted selection. For example, the single nucleotide polymorphism (SNP) derived 
from Bmyl gene sequence have been extensively used to select for high diastatic power and fermentability (C. D. Li, unpublished data). With development of genomics, it is expected that more functional genes will be incorporated into barley linkage maps. This will present great value for QTL analysis of malting quality.

QTLs for the same traits have been mapped to different chromosomes or regions by different researchers. These could be due to environmental factors and methods for quality assessment (Henry et al. 1996). Hayes et al. (1996) suggested that the different QTLs in different populations for a same trait are due to genotype-specificity of the QTLs. This limits straightforward application of the results from one population to another. On the other hand, it implies that not all favourable QTLs are fixed in elite germplasm. An alternative to attempting to extend the QTL results from one population to another is to integrate information from a range of germplasm with the aim of identifying regions of the genome that may affect target-trait expression. This information can be used to classify germplasm and design matings that will maximise the probability of accumulating favourable alleles.

Several malting quality traits have been associated with no QTL (e.g. grain thickness) or few QTLs detected with small effect on the phenotypic variation (one QTL for grain shape accounting for $5 \%$ of phenotypic variation). These traits may be controlled by a large number of genes, or environmental factors may play a major role in the phenotypic expression. So far, there has been little success to map these QTLs for marker assisted selection. In such cases, an alternative would be to generate large populations, use marker-assisted selection to form a pool of improved lines, and rely on phenotypic selection to pick out the best line.

\section{Impact of genomics on understanding of the genetics of quality}

Classical molecular approaches have generated a strong basis of genetic information in barley. However, modern genomic approaches have now begun to expand this knowledge base significantly. Maps of the barley genome are now being complemented by data generated by genomic analysis. For example, simple sequence repeat (SSR) markers (Ablett et al. 2003, this issue) have been isolated traditionally from genomic libraries but are now being expanded by addition of SSR identified in gene sequence data (Holton et al. 2002) generated in genomic studies.

The sequencing of plant genomes is generating a large amount of sequence information of value in barley. The sequences of the Arabidopsis and more specifically the rice genome (Goff et al. 2002) provide a major base of data for barley research. The volume of barley sequence data continues to grow rapidly. A complete genome sequence for barley is unlikely to be completed in the near future but gene sequences and the sequences of gene rich regions are rapidly becoming available. Based on a large number of expressed sequence tag (EST) and gene sequences, a comprehensive comparative map between rice and wheat is now available (Sorrells et al. 2003). Similar research for a rice-barley comparison based on the large number EST and gene sequences is under way. Comparative genomics approaches would provide an efficient way to identify useful markers and candidate genes associated with barley quality from rice to barley.

Sequencing of cDNA libraries from many barley tissues has generated large amounts of EST data with barley-specific sequences (Michalek et al. 2002). A significant proportion of the barley genome is now covered by EST data. These cDNA clones have been used to produce microarrays (Aharoni and Vorst 2002) allowing detailed analysis of patterns of gene expression.

Genes expressed in grain development and during germination are likely to be important in determining grain quality. Genes expressed during seed development will determine the composition of the mature grain. Malting performance will also be influenced by the genes expressed during germination. Potokina et al. (2002) recently reported analysis of gene expression in different tissues of germinating barley using 1440 unique genes on a microarray. Extension of these studies to include more genes and comparisons of genotypes should reveal the identity of key genes influencing the malting process.

Analysis of allelic variation in key genes using genomic approaches is advancing our understanding of barley quality. SNP analysis and associated genetic approaches allow alleles to be efficiently distinguished and associated with traits of interest (Rafalski 2002). Detailed knowledge of the variation in gene sequence and resulting amino acid substitutions in $\beta$-amylase genes has been used to explain key differences in $\beta$-amylase activity, a major quality trait in barley ( $\mathrm{Li}$ et al. 2002). Similar outcomes can be expected as variation in the sequences of other genes is determined. SNP analysis of variation in the barley genes (Bundock et al. 2002; Kanazin et al. 2002) will provide opportunities for high throughput analysis of sequence variation in key genes. Combination of this type of information with detailed expression data from microarray experiments is likely to accelerate the rate of increase in knowledge of the molecular basis of barley quality.

Other barley genome information and tools are also becoming available. The production of large insert libraries (e.g. Bacterial Artificial Chromosome (BAC) libraries) from the genome of barley and other cereals has provided a key resource for the identification of barley genes by positional cloning. Physical mapping of genes is aided by synteny in cereal genomes with the rice genome sequence, providing an important reference for barley gene analysis (Feuillet and Keller 2002).

Barley transformation provides another important tool for analysis of the molecular basis of barley quality (Jacobsen 
et al. 2000). Manipulation of candidate genes in transgenic barley allows testing of their role in barley quality. Insertional mutagenesis based upon the introduction of transposable elements into barley by transformation has been developed as a technique for analysis of gene function. This should allow confirmation of gene function for many genes associated with grain quality. Higher throughput transformation techniques than those currently available will be necessary to screen candidate genes for gain of function.

The application of genomics to barley is likely to result in the large-scale association of specific alleles at each quality locus with quality phenotypes. This should provide a growing array of tools for both analysis of the genetics and molecular basis of quality and for selection in breeding.

\section{References}

Ablett GA, Karakousis A, Banbury L, Cakir M, Holton TA, Langridge P, Henry RJ (2003) Application of SSR markers in the construction of Australian barley genetic maps. Australian Journal of Agricultural Research 54, 1187-1195.

Agu RC, Palmer GH (1997) $\alpha$-Glucosidase activity of sorghum and barley malts. Journal of the Institute of Brewing 103, 25-29.

Aharoni A, Vorst O (2002) DNA microarrays for functional plant genomics. Plant Molecular Biology 48, 99-118. doi:10.1023/A: 1013734019946

Alison MJ, Cowe I, McHale R (1976) A rapid test for the prediction of malting quality of barley. Journal of the Institute of Brewing 82, $166-167$.

Alison M (1986) Relationships between milling energy and hot water extract values of malts from some modern barleys and their parental cultivars. Journal of the Institute of Brewing 92, 604-607.

Allosio-Ouarnier N, Quemener B, Bertrand D, Boivin P (2000) Application of high performance anion exchange chromatography to the study of carbohydrate changes in barley during malting. Journal of the Institute of Brewing 106, 45-52.

Arends AM, Fox GP, Henry RJ, Marschke RJ, Symons MH (1995) Genetic and environmental variation in the diastatic power of Australian barley. Journal of Cereal Science 21, 63-70.

Asano K, Shinagawa K, Hashimoto N (1982) Characterisation of haze-formation proteins of beer and their roles in chill haze formation. Journal of the American Society of Brewing Chemists 40, $147-154$.

Aspegren K, Mannonen L, Ritala A, Puupponen-Pimia R, Kurten U, Salmenkallio-Marttila M, Kauppinen V, Terri TH (1995) Secretion of a heat stable fungal $\beta$-glucanase from transgenic, suspensioncultured barley cells. Molecular Plant Breeding 1, 91-99.

Australian Lot Feeders Association (2001) Lotfeeding. Annual Report, September 14-17, Australian Lot Feeders Association. (Agricultural Publishers: Melbourne)

Autio K, Mannonen L, Pietila K, Koskinen M, Siika-Aho M, Linko M, Morgan A (1996) Incubation of barely kernel sections with purified cell wall degrading enzymes. Journal of the Institute of Brewing $102,427-432$

Axcell B (1998) Malt analysis-prediction or predicament. Master Brewers Association of the Americas Technical Quarterly 35, $28-30$.

Backes G, Graner A, Foroughi-Wehr B, Fischbeck G, Wenzel G, Jahoor A (1995) Localization of quantitative loci (QTL) for agronomic important characters by the use of a RFLP map in barley (Hordeum vulgare L.). Theoretical and Applied Genetics 90, 294-302.
Bamforth CW, Kanauchi M (2001) A simple model for the cell wall of the starchy endosperm in barley. Journal of the Institute of Brewing 107, 235-240.

Bathgate GN, Palmer GH (1973) The in vivo and in vitro degradation of barley and malt starch granules. Journal of the Institute of Brewing 79, 402-406.

Beecher B, Smidansky ED, See D, Blake TK, Giroux MJ (2001) Mapping and sequence analysis of barley hordoindolines. Theoretical and Applied Genetics 102, 833-840.

Benech-Arnold R (2002) Bases of pre-harvest sprouting resistance in barley: Physiology, molecular biology and Environmental control of dormancy in the barley grain. In 'Barley science: recent advances from molecular biology to agronomy of yield and quality'. (Eds GA Slafer, JL Molina-Cano, R Savin, JL Araus, I Romagos) (Food Products Press: New York)

Benetrix F, Sarrafi A, Autran J-C (1994) Effects of genotype and nitrogen nutrition on protein aggregates in barley. Cereal Chemistry 71, 75-82.

Bezant JH, Laurie DA, Pratchett N, Chøjecki J, Kearsey MJ (1997) Mapping of QTL controlling NIR predicted hot water extract and grain nitrogen content in a spring barley cross using marker-regression. Plant Breeding 116, 141-145.

Bhullar SS, Jenner CF (1996) Effects of temperature on the conversion of sucrose to starch in the developing wheat endosperm. Australian Journal of Plant Physiology 13, 605-615.

Bishop LR (1930) The nitrogen content and quality of barley. Journal of the Institute of Brewing 36, 352-369.

Boss DL, Bowman JGP, Surber LMM, Anderson DC, Blake TK (1999) Feeding value of two Lewis $\times$ Baronesse recombinant inbred barley lines, BB13 and LB30, for finishing steers. In 'Proceedings of the American Society of Animal Science, Western Section'. Vol. 50, pp. 3.

Bowman JGP, Blake TK, Surber LMM, Habernicht TK, Daniels TK, Daniels JT (1996) Genetic factors controlling digestibility of barley for ruminants. Proceedings of Western Section of American Society of Animals 47, 257-260.

Borem A, Mather DE, Rasmusson DC, Fulcher RG, Hayes PM (1999) Mapping quantitative trait loci for starch granule traits in barley. Journal of Cereal Science 29, 153-160. doi:10.1006/JCRS.1998. 0217

Brennan CS, Smith DB, Harris N, Shewry PR (1998) The production and characterisation of Hor3 null lines of barley provides new information on the relationship of $\mathrm{D}$ hordein to malting performance. Journal of Cereal Science 28, 291-299.

Briggs DE (Ed.) (1978) 'Barley.' (Chapman and Hall: London)

Briggs DE, Hough JS, Stevens R, Young TW (1981) 'Malting and barley brewing science.' Vol. 1. 2nd edn (Chapman and Hall: London)

Briggs DE, Woods JL (1993) Dormancy in malting barley: studies on drying, storage, biochemistry and physiology. HGCA Project Report No. 84, p.146.

Broadbent RE, Palmer GH (2001) Relationship between $\beta$-amylase activity, steeliness, mealiness, nitrogen fractions on the barley grain. Journal of the Institute of Brewing 107, 349-354.

Brown AHD (1987) Barley. In 'Isozymes in plant genetics and breeding. Part B'. (Eds SD Tanksley, TJ Orton) pp. 55-77. (Elsevier Science Publishing: Amsterdam)

Bundock P, Christopher JT, Eggler P, Ablett G, Henry RJ, Holton TA (2002) Single nucleotide polymorphisms in cytochrome P450 genes from barley. Theoretical and Applied Genetics 106, 676-682.

Burton RA, Zhang XQ, Hrmova M, Fincher GB (1999) A single limit dextrinase gene is expressed both in the developing endosperm and in germinated grains of barley. Plant Physiology 119, 859-887. doi:10.1104/PP.119.3.859 
Buttimer ET, Briggs DE (2000a) Characterisation of solubilized forms of bound $\beta$-amylase released by various agents. Journal of the Institute of Brewing 106, 71-82.

Buttimer ET, Briggs DE (2000b) Mechanisms of the release of bound $\beta$-amylase. Journal of the Institute of Brewing 106, 83-94.

Cannell M, Karp A, Isaac PG, Shewry PR (1992) Chromosomal assignment of genes in barley using telosomic wheat-barley addition lines. Genome 35, 17-23.

Cassab GI, Varner JE (1988) Cell wall proteins. Annual Review of Plant Physiology and Plant Molecular Biology 39, 321-353. doi:10.1146/ANNUREV.PP.39.060188.001541

Chandra GS, Proudlove MO, Baxter ED (1999) The structure of barley endosperm - an important determinant of malt modification. Journal of the Science of Food and Agriculture 79, 37-46. doi:10.1002/(SICI)1097-0010(199901)79:13.3.CO;2-O

Chowdhury SL, Wardlaw IF (1978) The effect of temperature on kernel development in cereals. Australian Journal of Agricultural Research 29, 205-223.

Collins HM, Logue SJ, Jefferies SP, Barr A (2001) Validation of markers for malt extract, DP, alpha amylase and beta amylase. In 'Proceedings of the 10th Australian Barley Technical Symposium'. Canberra. http://www.regional.org.au/au/abts/2001/w2/collins.htm

Collins HM, Panozzo JF, Logue SJ, Jefferies SP, Barr AR (2003) Mapping and validation of chromosome regions associated with high malt extract in barley (Hordeum vulgare L.). Australian Journal of Agricultural Research 54, 1223-1240.

Cook AH (1962) Barley and malt: biology, biochemistry and technology.' (Academic Press: New York)

Coventry SJ, Collins HM, Barr AR, Jefferies SP, Chalmers KJ, Logue SJ, Langridge P (2003a) Use of putative QTLs and structural genes in marker assisted selection for diastatic power in malting barley (Hordeum vulgare L.). Australian Journal of Agricultural Research 54, 1241-1250.

Coventry SJ, Barr AR, Eglinton JK, McDonald GK (2003b) The determinants and genome locations influencing grain weight and size in barley (Hordeum vulgare L.). Australian Journal of Agricultural Research 54, 1103-1115.

Crosbie GB, Portman PA (1977) A comparison of screening tests for feed and malting quality for barley. Journal of Australian Institute of Agricultural Sciences 43, 160-161.

Dahl SW, Rasmussen SK, Hejgaard J (1996) Heterologous expression of three plant serpins with distinct inhibitory specificities. The Journal of Biological Chemistry 271, 25083-25088. doi:10.1074/ JBC.271.41.25083

Darlington HF, Tesci L, Harris N, Griggs DL, Cantell IC, Shewry PR (2000) Starch granule associated proteins in barley and wheat. Journal of Cereal Science 32, 21-29. doi:10.1006/JCRS.2000.0312

Duffus CM, Cochrane MP (1993) Grain structure and composition. In 'Barley: Genetics, biochemistry, molecular biology and biotechnology'. (Ed. PR Shewry) pp. 291-318. (CAB International: Oxon, UK)

Eagles HA, Bedggood AG, Panozzo JF, Martin PJ (1995) Cultivar and environmental effects on malting quality in barley. Australian Journal of Agricultural Research 46, 831-844.

Edney MJ (1996) Barley. In 'Cereal grain quality'. (Eds RJ Henry, PS Kettlewell) pp. 113-151. (Chapman and Hall: London)

Eglinton JK, Langridge P, Evans DE (1998) Thermostability variation in alleles of barley beta-amylase. Journal of Cereal Science 28, 301-309.

Ellis RP, Swanston JS, Bruce FM (1979) A comparison of some rapid screening tests for malting quality. Journal of the Institute of Brewing 85, 282-285.

Emebiri LC, Moody DB, Panozzo JF, Chalmers KJ, Kretschmer JM, Ablett GA (2003) Identification of QTLs associated with variations in grain protein concentration in two-row barley. Australian Journal of Agricultural Research 54, 1211-1221.

Evans DE, Hejgaard J (1999) The impact of malt derived proteins on beer foam quality Part I: The effect of germination and kilning on the level of protein Z4, Protein Z7 and LTP1. Journal of the Institute of Brewing 105, 159-169.

Evans DE, Sheehan MC, Stewart DC (1999) The impact of malt derived proteins on beer foam quality. Part I: The influence of malt foam-positive proteins and non-starch polysaccharides on beer foam quality. Journal of the Institute of Brewing 105, 171-177.

Evers AD, Blakeney AB, O'Brien L (1999) Cereal structure and composition. Australian Journal of Agricultural Research 50, 629-650. doi:10.1071/AR98158

Feuillet C, Keller B (2002) Comparative genomics in the grass family: Molecular characterization of grass genome structure and evolution. Annals of Botany 89, 3-10. doi:10.1093/AOB/MCF008

Fincher GB (1975) Morphology and chemical composition of barley endosperm cell walls. Journal of the Institute of Brewing 81, $116-122$.

Fincher GB, Stone BA (1986) Cell walls and their components in cereal grain technology. In 'Advances in cereal science and technology'. (Ed. Y Pommaranz) Vol. 8, pp. 207-295. (American Association of Cereal Chemists: St Paul, MN)

Fix G (1989) 'Principles of brewing science.' (Brewer Publications: New York)

Fontanini D, Jones BL (2001) Study of metallopeptidase isoenzymes from malted barley (Hordeum vulgare cv. Morex). Journal of Agricultural and Food Chemistry 49, 4903-4911. doi:10.1021/ JF0104331

Franckowiak JD, Lundqvist U, Konishi T (1996) New and revised names for barley genes. Barley Genetics Newsletter 26, 4-8.

Freeman PL (1984) Physiological aspects of enzymic modification in malting barley. Dissertation Abstracts International 45, 992.

Furtado A, Henry RJ, Scott KJ, Meech S (2003) The promoter of the asi gene directs expression in the maternal tissues of the seed in transgenic barley. Plant Molecular Biology 52, 787-799.

Gibson CE, Evans DE, Proudlove MO (1996) Protein Z4 and beer foam. Ferment 9, 81-84.

Glennie-Holmes M (1995a) Studies on barley and malt with the rapid viscoanalyser I: The effects of variations in physical and chemical parameters. Journal of the Institute of Brewing 101, 11-18.

Glennie-Holmes M (1995b) Studies on barley and malt with the rapid viscoanalyser II: The effects of modification on viscograms. Journal of the Institute of Brewing 101, 19-28.

Glennie-Holmes M (1995c) Studies on barley and malt with the rapid viscoanalyser III: The prediction of malting potential from viscograms. Journal of the Institute of Brewing 101, 29-32.

Glennie-Holmes M (1995d) Studies on barley and malt with the rapid viscoanalyser IV: Studies on barley and malt with the rapid viscoanalyser. Journal of the Institute of Brewing 101, 33-38.

Goff SD, Ricke D, Lan T-H, Presting C, Wang R, Dunn M, Glazebrook J, Sessions A, Oeller P, Varma H, Hadley D, Hutchison D, Martin C, Katagiri F, Lange BM, Moughamer T, Xia Y, Budworth P, Zhong JP, Miguel T, Paszkowski U, Zhang S, Colbert M, Sun WL, Chen L, Cooper B (2002) A draft sequence of the rice genome (Oryza sativa L. ssp. japonica). Science 296, 92-100. doi:10.1126/SCIENCE. 1068275

Grimes KH, Briggs DE (1995) Release and activation of barley $\beta$-amylase. Journal of the Institute of Brewing 101, 337-343.

Grimes KH, Briggs DE (1996) The release of bound $\beta$-amylase by macromolecules. Journal of the Institute of Brewing 102, 261-270.

Guerin JR, Lance RCM, Wallace W (1992) Release and activation of barley beta-amylase by malt endopeptidases. Journal of Cereal Science 15, 5-14. 
Guerin J, Lance R, Brown A, Abbott D (1994) Mapping of malt endopeptidase, NADH diaphorase and esterase loci on barley chromosome 3L. Plant Breeding 112, 279-284.

Hafi A, Rodriguez A (2000) Projection of regional feed demand and supply in Australia. Report by Grains Research and Development Corporation and Australian Bureau of Agricultural and Resource Economics.

Han JY, Schwartz PB (1996) Arabinoxylan composition in barley, malt and beer. Journal of the American Society of Brewing Chemists 54, 216-220.

Han F, Ullrich SE, Chirat S, Menteur S, Jestin L, Sarrafi O, Hayes PM, Jones BL, Blake TK, Wessenberg D, Kleinhofs A, Kilian A (1995) Mapping of $\beta$-glucan content and $\beta$-glucanase activity loci in barley grain and malt. Theoretical and Applied Genetics 91, 921-927.

Hayes PM, Briceno G, Cerono J (1996) Using QTL in barley. In 'Proceedings V International Oat Conference and VII International Barley Genetics Symposium'. Saskatoon. (Eds G. Scoles, B Rossnagel) pp. 182-187. (University of Saskatchewan: Saskatoon, Saskatchewan)

Hayes PM, Castro A, Marquez-Cedillo L, Corey A, Henson C, Jones B, Kling J, Mather D, Matus I, Rossi C, Sato K (2001) A summary of published barley QTL reports. http://www.css.orst.edu/barley/ nabgmp/qtlsum.htm.

Hayes PM, Liu BH, Knapp SJ, Chen F, Jones B, Blake TK, Franckowiak G, Rasmusson D, Sorrells M, Ullrich SE, Wesenberg D, Kleinhofs A (1993) Quantitative trait locus effects and environmental interaction in a sample of North American barley germplasm. Theoretical and Applied Genetics 87, 392-401.

Hejgaard J, Kaesgaard P (1983) Purification and properties of the major antigenic beer protein of barley origin. Journal of the Institute of Brewing 89, 402-410.

Henry RJ (1984) A rapid method for the determination of diastatic power. Journal of the Institute of Brewing 90, 37-39.

Henry RJ (1985) A comparative study of the total $\beta$-glucan content of some Australian barleys. Australian Journal of Experimental Agriculture 25, 424-427.

Henry RJ (1986) Genetic and environmental variation in the pentosan and $\beta$-glucan contents of barley and their relation to malting quality. Journal of Cereal Science 4, 269-277.

Henry RJ (1987) Pentosans and (1-3), (1-4)- $\beta$-glucan concentrations in endosperm and whole grain of wheat, barley, oats and rye. Journal of Cereal Science 6, 253-258.

Henry RJ (1988) The carbohydrates of barley grains. A review. Journal of the Institute of Brewing 94, 71-78.

Henry RJ, Cowe I (1990) Factors influencing the hardness (milling energy) and malting quality of barley. Journal of the Institute of Brewing 96, 135-136.

Henry RJ, Weining S, Inkerman PA (1996) Marker assisted selection for quality in barley and oat. In 'Proceedings V International Oat Conference and VII International Barley Genetics Symposium'. Saskatoon. (Eds G Scoles, B Rossnagel). pp. 167-173. (University of Saskatchewan: Saskatoon, Saskatchewan)

Holton TA, Christopher J, McLure L, Henry R (2002) Identification of polymorphic SSR markers from expressed gene sequences of wheat and barley. Molecular Breeding 9, 63-71.

Hoseney RC (1986) Minor constituents of cereals In 'Principles of cereal science and technology'. pp. 89-110. (American Association of Cereal Chemists: St Paul, MN)

Howard KA, Gayler KR, Eagles HA, Halloran GM (1996) The relationship between D-Hordein and malting quality in barley. Journal of Cereal Science 24, 47-53. doi:10.1006/JCRS.1996.0036

Hough JS (1985)The biotechnology of malting and brewing. In 'Cambridge Studies in Biotechnology 1'. (Cambridge University Press: Cambridge)
Izawa M, Kano Y, Koshino S (1993) Relationship between structure and solubitity of (1-3), (1-4)- $\beta$-glucan from barley. Journal of the American Association of Brewing Chemists 51, 123-127.

Izydorczyk MS, Macgregor AW, Billiaderis CG (2001) Effects of malting on phase transition behaviour of starch in barley cultivars with varying amylose content. Journal of the Institute of Brewing 107, 119-128.

Jacobsen JV, Matthews PM, Abbott DC, Wang MB, Waterhouse PM (2000) Transgenic Barley. In 'Transgenic cereals'. (Eds L O'Brien, RJ Henry) pp. 88-114. (American Association of Cereal Chemists: St Paul, MN)

Janes PW, Skerritt JH (1993) High performance liquid chromatography of barley proteins: Relative quantities of hordein fractions correlate with malt extract. Journal of the Institute of Brewing 99, 77-84.

Jones BL, Marinac LA (1995) Barley LTP1(PAPI) and LTP2: Inhibitors of green malt cysteine enodproteinases. Journal of the American Society of Brewing Chemists 53, 194-195.

Jones BL, Marinac LA (2002) The effect of mashing on malt endoproteolytic activities. Journal of Agricultural and Food Chemistry 50, 858-864. doi:10.1021/JF0109672

Kaiser AG (1999) Increasing the utilisation of grain when fed whole to ruminants. Australian Journal of Agricultural Research 50, 737-756. doi:10.1071/AR98164

Kanauchi M, Bamforth CW (2002) Enzymic digestion of walls purified from the starchy endosperm of barley. Journal of the Institute of Brewing 108, 73-77.

Kanazin V, Talbert H, See D, DeCamp P, Nevo E, Blake T (2002) Discovery and assay of single nucleotide polymorphisms in barley (Hordeum vulgare). Plant Molecular Biology 48, 529-537. doi:10.1023/A:1014859031781

Kaneko T, Kihara M, Zhang WS, Ito K, Aida Y, Takeda K (2000) Variation and utiliztion of $\alpha$-amylase thermostability in barley. In 'Proceedings of the 8th International Barley Genetics Symposium'. (Ed. S. Logue) Vol. 1, pp. 252-254. (Adelaide University: Glen Osmond, S. Aust.)

Kauffman JA, Mills ENC, Brett G, Fido RJ, Tatham AS, Shewry PR, Onishi A, Proudlove MO, Morgan MRA (1994) Immunological characterisation of barley polypeptides in lager foam. Journal of the Science of Food and Agriculture 66, 345-355.

Kenn DA, Dagg AHS, Stuart IM (1993) Effect of environment and genotype on the fermentability of malt produced from four Australia barley varieties. Journal of the American Association of Brewing Chemists 51, 119-222.

Kieliszewski MJ, Leykam JF, Lamport DTRA (1990) Structure of the threonine rich extensin from Zea mays. Plant Physiology 92, 316-326.

Kihari M, Kaneko T, Ito K (1998) Genetic variation of $\beta$-amylase thermostability among varieties of barley, Hordeum vulgare L., in relation to malting quality. Plant Breeding 117, 425-428.

Kleinhofs A, Han F (2002) Molecular mapping of the barley genome. In 'Barley science: recent advances from molecular biology to agronomy of yield and quality'. (Eds GA Slafer, JL Molina-Cano, R Savin, JL Araus, I Romagosa) pp. 31-63. (Food Products Press: New York)

Langridge P, Karakousis A, Collins N, Kretschmer J, Manning S (1995) A consensus linkage map of barley. Molecular Breeding 1, 389-395.

Lenior P, MacGregor AW, Moll M, Duassant J (1984) Identification of debranching enzymes from barley and malt by isoelectric focusing. C.R. Academy of Science Series 298, 243-248.

Li CD, Langridge P, Zhang XQ, Eckstein PE, Rossnagel BG, Lance RCM, Lefol EB, Lu MY, Harvey BL, Scoles GJ (2002) Mapping of barley (Hordeum vulgare L.) beta-amylase alleles in which an amino acid substitution determines beta-amylase isoenzyme type 
and the level of free beta-amylase. Journal of Cereal Science $\mathbf{3 5}$, 39-50. doi:10.1006/JCRS.2001.0398

Li CD, Langridge P, Lance RCM, Xu GB, Fincher GB, Xu P (1999b) Seven members of the $(1 \rightarrow 3)$-beta-glucanase gene family in barley (Hordeum vulgare) are clustered on the long arm of chromosome 3 (3HL). Theoretical and Applied Genetics 92, 791-796.

Li CD, Tarr A, Lance RMC, Harasymow S, Ulmann J, Westcot S, Young KJ, Grime CR, Cakir M, Broughton S, Appels R (2003) A major QTL controlling seed dormancy and pre-harvest sprouting/grain $\alpha$-amylase in two-rowed barley (Hordeum vulgare L.). Australian Journal of Agricultural Research 54, 1303-1313.

Li CD, Zhang XQ, Eckstein P, Rossnagel BR, Scoles GJ (1999a) A polymorphic microsatellite in the limit dextrinase gene of barley (Hordeum vulgare). Molecular Breeding 5, 569-577. doi:10.1023/ A: 1009692207966 .

Loi L, Ahluwalia B, Fincher GB (1988) Chromosomal location of genes encoding barley (1-3,1-4)- $\beta$-glucan 4-glucanohydrolases. Australian Journal of Plant Physiology 87, 300-302.

Longstaff MA, Bryce JH (1993) Development of limit dextrinase in germinated barley (Hordeum vulgare L.). Evidence of proteolytic activation. Plant Physiology 101, 881-889.

Lusk LT, Duncombe GR, Kay SB, Navarro A, Ryder D (2001) Barley-glucan and beer foam stability. Journal of the American Society of Brewing Chemists 59, 183-186.

Lusk LT, Goldstein H, Ryder D (1995) Independent role of beer proteins, melanoidins and polysaccharides in foam formation. Journal of the American Society of Brewing Chemists 53, 93-103.

MacGregor AW (1987) $\alpha$-Amylase, limit dextrinase and $\alpha$-glucosidase enzymes in barley and malt. CRC Critical Reviews in Biotechnology 5, 117-128.

MacGregor AW (1996) Malting and brewing science: challenges and opportunities. Journal of the Institute of Brewing 102, 97-102.

MacGregor AW, Balance DL (1980) Hydrolysis of large and small starch granules from normal and waxy barley cultivars by $\alpha$-amylases from barley malt. Cereal Chemistry 57, 397-402.

MacGregor AW, Bazin SL, Izydorczyk MS (2002) Gelatinisation characteristics and enzyme susceptibility of different types of barley starch in the temperature range $48-72^{\circ} \mathrm{C}$. Journal of the Institute of Brewing 108, 43-47.

MacGregor AW, Bazin SL, Schroeder SW (2002) Effect of starch hydrolysis products on the determination of limit dextrinase inhibitors in barley and malt. Journal of Cereal Science 35, 17-28. doi:10.1006/JCRS.2001.0408.

MacGregor AW, Bhatty RS (Eds) (1993) 'Barley: chemistry and technology.' (American Association of Cereal Chemists: St. Paul, $\mathrm{MN})$

MacLeod LC, Duffus CM (1988) Reduced starch content and sucrose synthase activity in developing endosperm of barley plants grown at elevated temperatures. Australian Journal of Plant Physiology 15, 367-375.

MacLeod LC, Lance RCM, Brown AHD (1991) Chromosomal mapping of the Glb 1 locus encoding 1-3 1-4-beta-d glucan 4-glucanohydrolase EI in barley. Journal of Cereal Science 13, 291-298.

Macnicol PK, Jacobsen JV, Keys MM, Stuart IM (1993) Effects of heat and water stress on malting quality and grain parameters of schooner barley grown in cabinets. Journal of Cereal Science $\mathbf{1 8}$, 61-68 doi:10.1006/JCRS.1993.1034

MBIBTC (1995) 'The Australian malting and brewing industry guidelines and evaluation protocols for malting barley.' Vol V. (The Malting and Brewing Industry Barley Technical Committee: Melbourne)

Manners DJ, Yellowlees D (1973) Studies on debraching enzymes. I. The limit dextrinase activity of extracts of certain higher plants and commercial malts. Journal of the Institute of Brewing 79, 377-385.
Marchylo BA, Kruger JE, Hatcher D (1986) High-performance liquid chromatographic and electrophoretic analysis of hordein during malting for two barley varieties of contrasting malting quality. Cereal Chemistry 63, 219-231.

May LH, Buttrose MS (1959) Physiology of cereal grain. II. Starch granule formation in the developing barley kernel. Australian Journal of Biological Sciences 12, 146-159.

McCleary BV (1992) Measurement of the content of limit dextrinase in cereal flours. Carbohydrate Research 227, 257-268. doi:10.1016/ 0008-6215(92)85076-C

Marquez-Cedillo LA, Hayes PM, Jones BL, Kleinhofs A, Legge WG, Rossnagel BG, Sato K, Ullrich SE, Wesenburg DM, The North American Barley Genome Mapping Project (2001) QTL analysis of malting quality in barley based on the doubled haploid progeny of two elite North American varieties representing different germplasm groups. Theoretical and Applied Genetics 103, 625-637.

Mather DE, Tinker NA, LaBerge DE, Edney M, Jones BL, Rossnagel BG, Legge WG, Briggs KG, Irvine RB, Falk DE, Kasha KJ (1997) Regions of the genome that affect grain and malt quality in a North American two-row barley cross. Crop Science 37, 544-554.

Meyer RC, Swanston JS, Young GR, Lawrence PE, Bertie A, Ritchie J, Wilson A, Brosnan J, Pearson S, Bringhurst T, Steele G, Aldis PR, Field M, Jolliffe T, Powell W, Thomas WTB (2001) A genome-based approach to improving barley for the malting and distilling industries. Home-Grown Cereals Authority Project Report No. 264.

Michalek W, Weschke W, Pleisser K-P, Graner A (2002) EST analysis in barley defines a unigene set comprising 4,000 genes. Theoretical and Applied Genetics 104, 97-103. doi:10.1007/S001220200011

Molina-Cano JL, Francesch M, Ellis RP, Perez-Vendrell AM, Ramo T, Voltas J, Brafau J (1997) Genetic and environmental variation in malting and feed barley quality. Journal of Cereal Science 25, 37-47.

Molina-Cano JL, Polo JP, Sopena A, Voltas J, Perez-Vendrell AM, Romagosa I (2000a) Mechanisms of malt extract development in barleys from different European regions II. Effect of barley hordein fractions on malt extract yield. Journal of the Institute of Brewing 106, 117-123.

Molina-Cano JL, Polo JP, Romera E, Araust JL, Zarco J, Swanston JS (2001) Relationships between barley hordeins and malting quality in a mutant of $\mathrm{cv}$. Triumph. I. Genotype by environment interaction of hordein content. Journal of Cereal Science 34, 285-294. doi:10.1006/JCRS.2001.0415

Molina-Cano JL, Ramo T, Ellis RP, Swanston JS, Bain H, Uribe-Echieverria T, Perez-Vendrell AM (1995) Effect of grain composition on water uptake by malting barley: A genetic and environmental study. Journal of the Institute of Brewing 101, 79-83.

Molina-Cano JL, Rubio A, Igartua E, Gracia P, Montoya JL (2000b) Mechanisms of malt extract development in barleys from different European regions I. Effect of environment and grain protein content on malt extract yield. Journal of the Institute of Brewing 106, $111-115$.

Molina-Cano JL, Sopena A, Polo JP, Bergareche C, Moralejo MA, Swanston JS, Gligewell SM (2002) Relationships between barley hordeins and malting quality in a mutant of cv. Triumph. II. Genetic and environmental effects on water uptake. Journal of Cereal Science 36, 39-50. doi:10.1006/JCRS.2002.0440

Morgan AG, Riggs TJ (1981) Effects of drought on yields and on grain and malt characters in spring barley. Journal of the Science of Food and Agriculture 22, 339-346.

Munck L, Gibbons G, Aastrup S (1981) Chemical and structural changes during malting, In 'Proceedings of the 18th European Brewery Convention Congress'. Copenhagen. pp. 11-33. (IRL Press Limited: Oxford, UK)

Nilan RA (1964) 'The cytology and genetics of barley 1951-1962'. Monographic supplement No. 3. (Washington State University Press: Pullman, WA) 
Oliveira AB, Rasmusson DC, Fulcher RG (1994) Genetic aspects of starch granule traits in barley. Crop Science 34, 1176-1180.

Osman AM, Coverdale SM, Cole N, Hamilton SE, de Jersey J, Inkerman PA (2002) Characterisation and assessment of the role of barley malt proteases during malting and mashing. Journal of the Institute of Brewing 108, 62-67.

Osman AM, de Jersey J, Inkerman PA (1996a) A novel approach to a differential assay of barley malt $\alpha$-glucosidases, maltase and maltooligosaccharide $\alpha$-glucosidase. In 'Proceedings of the 46th Australian Cereal Chemistry Conference'. (Ed. CW Wrigley) pp. 172-175. (Royal Australian Chemical Institute: Melbourne)

Osman AM, de Jersey J, Inkerman PA (1996b) The specific measurement of starch degrading enzymes in a common extract from barley malt. In 'Proceedings of the 46th Australian Cereal Chemistry Conference'. (Ed. CW Wrigley) pp. 208-212. (Royal Australian Chemical Institute: Melbourne)

Overnell-Roy KH, Nelson ML, Froseth JA, Parish SM, Martin EL (1998a) Variation in chemical composition and nutritional quality among barley cultivars for ruminants: I. Steer finishing performance, diet digestibilities and carcass characteristics. Canadian Journal of Animal Science 78, 369-375.

Overnell-Roy KH, Nelson ML, Froseth JA, Parish SM (1998b) Variation in chemical composition and nutritional quality among barley cultivars for ruminants: II. Digestion, ruminal characteristics and in situ disappearance kinetics. Canadian Journal of Animal Science 78, 377-388.

Overnell-Roy KH, Nelson ML, Westburg HH, Froseth JA (1998c) Effects of barley cultivar on energy and nitrogen metabolism of lambs. Canadian Journal of Animal Science 78, 389-397.

Oziel A, Hayes PM, Chen FQ, Jones B (1996) Application of quantitative trait locus mapping to the development of winter-habit malting barley. Plant Breeding 115, 43-51.

Palmer GH (1983) Malting and mashing. In 'An introduction to brewing and science technology'. pp. 10-27. (The Institute of Brewing: London)

Palmer GH, Agu RC (1999) Effect of mashing temperature and endo- $\beta$-glucanase on $\beta$-glucan content of malt worts. Journal of the Institute of Brewing 105, 233-235.

Panozzo JF, Eagles HA, Cawood RJ, Wootton M (1999) Wheat spike temperatures in relation to varying environmental conditions. Australian Journal of Agricultural Research 50, 997-1005. doi:10.1071/AR98142

Paris M, Jones MGK, Eglinton JK (2002) Genotyping a single nucleotide polymorphism for selection of barley $\beta$-amylase alleles. Plant Molecular Biology Reporter 20, 149-159.

Perez-Vendrell AM, Brufau J, Molina-Cano JL, Francesch M, Guasch J (1996) Effects of cultivar and environment on $\beta$-(1,3)-(1,4)-D-glucan content and acid extract viscosity of Spanish barleys. Journal of Cereal Science 23, 285-292. doi:10.1006/ JCRS.1996.0029

Petterson DS, Harris DJ, Rayner CJ, Blakney AB, Choct M (1999) Methods for analysis of premium livestock grains. Australian Journal of Agricultural Research 50, 775-787. doi:10.1071/ AR98166

Potokina E, Sreenivasula N, Altschmied L, Michalek W, Graner A (2002) Differential gene expression during seed germination in barley (Hordeum vulgare L.). Functional and Integrative Genomics 2, 28-39. doi:10.1007/S10142-002-0050-X

Poulle M, Jones BL (1988) A proteinase from germinating barley. I. Purification and some physical properties of a $30 \mathrm{kD}$ cysteine endoproteinase from green malt. Plant Physiology 88, 1454-1460.

Powell W, Caliagari PDS, Swanston JS, Jinks JL (1985) Genetic investigations into $\beta$-glucan content in barley. Theoretical and Applied Genetics 71, 461-466.
Qi X, Stam P, Lindhout P (1996) Comparison and integration of four barley genetic maps. Genome 39, 379-394.

Rafalski JA (2002) Novel genetic mapping tools in plants: SNPs and LD-based approaches. Plant Science 162, 329-333. doi:10.1016/ S0168-9452(01)00587-8

Rassmuson DC (1985) 'Barley.' (American Society of Agronomy: Madison, WI)

Romagosa I, Han F, Clancy JA, Ullrich SE (1999) Individual locus effects on dormancy during seed development and after ripening in barley. Crop Science 39, 74-79.

Roumeliotis S, Collins HM, Logue SJ, Willsmore KL, Jefferies SP, Barr AR (1999) Implication of thin husk. In 'Proceedings of the 9th Australian Barley Technical Symposium'. Melbourne. http://www.regional.org.au/au/abts/1999/roumeliotis.htm

Rowe JB, Choct M, Pethick DW (1999) Processing cereal grains for animal feeding. Australian Journal of Agricultural Research 50, 721-736. doi:10.1071/AR98163

Savin R, Nicolas ME (1996) Effects of short periods of drought and high temperature on grain growth and starch accumulation of two malting barley cultivars. Australian Journal of Plant Physiology 23, 201-210.

Savin R, Nicolas ME (1999) Effects of timing of heat stress and drought on growth and quality of barley grains. Australian Journal of Agricultural Research 50, 357-364.

Savin R, Stone PJ, Nicolas ME, Wardlaw IF (1997) Grain growth and malting quality of barley 1 . Effects of heat stress and moderately high temperature. Australian Journal of Agricultural Research 48, 615-624.

Sheehan MC, Skerritt JH (1997) Identification and characterisation of beer polypeptides derived from barley hordeins. Journal of the Institute of Brewing 107, 297-306.

Shewry PR (1993) Barley seed proteins. In 'Barley: chemistry and technology'. (Eds AW MacGregor, RS Bhatty) pp. 131-197. (American Association of Cereal Chemists: St Paul, MN)

Sissons MJ, Lance RCM, Sparrow DHB (1992a) Studies on limit dextrinase in barley. I. purification of malt limit dextrinase and production of specific monospecific antibodies. Journal of Cereal Science 16, 107-116.

Sissons MJ, Lance RCM, Sparrow DHB (1992b) Studies on limit dextrinase in barley. II. Application of an ELISA and immunoblotting to studies of genetic variability and malting effects. Journal of Cereal Science 16, 117-128.

Sissons MJ, Lance RCM, Sparrow DHB (1993) Studies on limit dextrinase in barley. III. Limit dextrinase in developing kernels. Journal of Cereal Science 17, 19-24. doi:10.1006/JCRS.1993.1003

Sissons MJ, Lance RCM, Wallace W (1994) Bound and free forms of limit dextrinase in barley and malt. Cereal Chemistry 71, 520-521.

Skerritt JH, Janes PW (1992) Disulphide-bonded 'gel protein' aggregates in barley: Quality-related differences in composition and reductive dissociation. Journal of Cereal Science 16, 219-235.

Smith DB (1990) Barley seed protein and its effects on malting and brewing quality. Plant, Varieties and. Seeds, New York 3, 63-80.

Smith L (1951) Cytology and genetics of barley. Botanical Review 17, $1-51,133-202,285-355$

Søgaad B, von Wettstein-Knowles P (1987) Barley: genes and chromosomes. Carlsberg Research Communications 52, 123-196.

Sorensen SB, Bech LM, Muldbjerg M, Beenfelt T, Breddam (1993) Barley lipid transfer protein 1 is involved in beer foam formation. Master Brewers Association of the Americas Technical Quarterly 30, 136-145.

Sorrells ME, La Rota CM, Bermudez-Kandianis CE, Greene RA, Kantety, Munkvold JD, Miftahudin Mahmoud A, Gustafson JP, Qi LL, Echalier B, Gill BS, Matthews D, Lazo G, Ghao S, Anderson OD, Edwards H, Linkiewicz AM, Dubcovsky J, Akhunov ED, 
Dvorak J, Zhang D, Nguyen HT, Peng J, Lapitan NLV, Gonzalez-Hernandez JL, Anderson JA, Hossain KG, Kalavacharla V, Kianian SF, Choi DW, Close TJ, Dilbirligi M, Gill KS, Steber C, Walker-Simmons MK, McGuire PE, Qualset CO (2003) Comparative DNA sequence analysis of wheat and rice genomes. Genome Research 13, 1818-1827.

Sparrow DHB, Lance RCM, Henry RJ (1988) 'Alternative end uses of barley.' (Royal Australian Chemical Institute: Melbourne)

Stenholm K, Home S (1999) A new approach to limit dextrinase and its role in mashing. Journal of the Institute of Brewing 105, 205-210.

Stewart DC, Freeman G, Evans DE (2000) Development and assessment of a small-scale wort filtration test for the prediction of beer filtration efficiency. Journal of the Institute of Brewing $\mathbf{1 0 6}$, 361-366.

Stewart DC, Hawthorne D, Evans DE (1998) Cold sterile filtration: A small-scale filtration test and investigation of membrane plugging. Journal of the Institute of Brewing 104, 321-326.

Stuart IM, Loi L, Fincher GB (1988) Varietal and environmental variations in $(1 \rightarrow 3,1 \rightarrow 4)$ - $\beta$-glucan and $(1 \rightarrow 3,1 \rightarrow 4)$ - $\beta$-glucanase potential in barley: Relationships to malting quality. Journal of Cereal Science 7, 61-71.

Swanston JS (1996) Associations of the waxy (wx) gene with malting quality characteristics in random inbred lines of barley. Journal of the Institute of Brewing 102, 355-358.

Swanston JS, Cowe IA (1989) A rapid technique to predict malting quality prior to harvest. Annals of Applied Biology 115, 529-532.

Swanston JS, Ellis RP, Rubio A, Perez-Vendrell A, Molina-Cano JL (1995) Differences in malting performance between barleys grown in Spain and Scotland. Journal of the Institute of Brewing 101, 261-265.

Swanston JS, Molina-Cano JL (2001) Beta-amylase activity and thermostability in two mutants derived from the malting barley cv. Triumph. Journal of Cereal Science 33, 155-161. doi:10.1006/ JCRS.2000.0364

Swanston JS, Taylor K (1988) A comparison of some rapid tests to assess extent of modification during a laboratory scale malting procedure. Journal of the Institute of Brewing 94, 311-314.

Tatham AS, Shewry PR (1995) Mini review: the S-poor prolamins of wheat, barley and rye. Journal of Cereal Science 22, 1-16.

Thomas WTB, Powell W, Swanston JS, Ellis RP, Chalmers KJ, Barua UM, Jack P, Lea V, Forster BP, Waugh R, Smith DB (1996) Quantitative trait loci for germination and malting quality characters in a spring barley cross. Crop Science 36, 265-273.

Tinker NA, Mather DE, Rossnagel BG, Kasha KJ, Kleinhofs A, Hayes PM, Falk DE, Ferguson T, Shugar LP, Legge WG, Irvine B, Choo TM, Briggs KG, Ullrich SE, Franckowiak JD, Blake TK, Graf RJ, Dofing SM, Saghai Maroof MA, Scoles GJ, Hoffman D, Dahleen LS, Kilian A, Chen F, Biyashev RM, Kudrna DA, Steffenson BJ (1996) Regions of the genome that affect agronomic performance in two-row barley. Crop Science 36, 1053-1062.

Ullrich SE (2002) Genetics and breeding of barley feed quality attributes. In 'Barley science-recent advances from molecular biology to agronomy of yield and quality'. (Eds GA, Slafer, J1 Molina-Cano, R Savin, JL Araus, I Romagosa) pp. 115-142. (Food Products Press: New York)

Ullrich SE, Clancy J, Eslick RF, Lance RCM (1986) Beta-glucan content and viscosity of extracts from Waxy Barley. Journal of Cereal Science 4, 279-285.

Vickers JE, Hamilton SE, de Jersey J, Henry RJ, Marschke RJ, Inkerman PA (1996) Assessment of Bacillus licheniformis -amylase as a candidate enzyme for genetic engineering of malting barley. Journal of the Institute of Brewing 102, 75-78.

Vietor RJ, Angelino SAGF, Voragen AGJ (1991) Arabinoxylans in barley, malt and wort. In 'Proceedings of the 23rd EBC Congress'. Lisbon. pp. 139-146. (Oxford University Press: New York)
Walker C, Dickie K, Biawa JP, Ueda T, Muller RE (2001) Prediction of extract potential in new barley varieties by measuring cell-wall breakdown. Journal of the Institute of Brewing 107, 167-174.

Wallace W, Lance RCM (1988) The protein reserves of the barley grain and their degradation during malting and brewing. Journal of the Institute of Brewing 96, 379-386.

Wallwork MAB, Logue SJ, MacLeod LC, Jenner CF (1998a) Effects of a period of high temperature during grain filling on the grain growth characteristics and malting quality of three Australian malting barleys. Australian Journal of Agricultural Research 49, 1287-1296.

Wallwork MAB, Logue SJ, MacLeod LC, Jenner CF (1998b) Effect of high temperature during grain filling on starch synthesis in the developing barley grain. Australian Journal of Plant Physiology 25, 173-181.

Wang M, Heimovaara-Dijstra S, van Duijn B (1995) Modulation of germination of embryos isolated from dormant and non-dormant barley grains by manipulation of endogenous abscissic acid. Planta 195, 586-592.

Wardlaw IF, Dawson IA, Munibi P (1989) The tolerance of wheat to high temperatures during reproductive growth. II. Grain development. Australian Journal of Agricultural Research 40, 1-13.

Weidner S, Paprocka J, Kamieniecki B, Zadernowski R (1993) The role of phenolic acids in dormancy of barley caryopes. In 'Proceedings of the 6th International Conference on Pre-Harvest Sprouting 1992'. (Eds MK Walker-Simmons, JL Reid) pp. 200-211. (American Association of Cereal Chemists: St Paul, MN)

von Wettstein-Knowles P (1992) Cloned and mapped genes: current status. In 'Barley genetics biochemistry, molecular biology and biotechnology'. Biotechnology in Agriculture No. 5. (Ed. PR Shewry) pp. 73-98. (CAB International: Oxon, UK)

Woodward JR, Fincher GB (1982) Substrate specificities and kinetic properties of two (13), (14)-D-Glucan endohydrolyase from germinating barley. Carbohydrate Research 106, 111-122. doi:10.1016/S0008-6215(00)80737-5

Worbel R, Jones BL (1992) Appearance of endoproteolytic enzymes during the germination of barley. Plant Physiology 100, 1508-1516.

Worbel R, Jones BL (1993) Identification and partial characterisation of high Mr neutral proteinases from 4-day germinated barley seeds, Journal of Cereal. Science 18, 225-237.

Wrigley CW (1999) Potential methodologies and strategies for the rapid assessment of feed-grain quality. Australian Journal of Agricultural Research 50, 789-805. doi:10.1071/AR98167

Yamada J (1981) Purification of oat debranching enzyme and occurrence of inactive debranching enzyme in cereals. Agricultural and Biological Chemistry 45, 1013-1015.

Zhang G, Chen J, Wang J, Ding S (2001) Cultivar and environmental effects on $(1 \rightarrow 3,1 \rightarrow 4)-\beta$-D-glucan and protein content in malting barley. Journal of Cereal Science 34, 295-301. doi:10.1006/ JCRS.2001.0414

Zhang N, Jones BL (1995a) Characterisation of germinated barley endoproteolytic enzymes by two-dimensional gel electrophoresis. Journal of Cereal Science 21, 145-153.

Zhang N, Jones BL (1995b) Development of proteolytic activities during barley malting and their localisation in the green malt kernel. Journal of Cereal Science 22, 147-155.

Zhang N, Jones BL (1999) Polymorphism of aspartic proteinases in resting and germinating barley seeds. Cereal Chemistry 76, 134-138.

Manuscript received 12 December 2002, accepted 30 September 2003 